\title{
SLC4A2 anion exchanger promotes tumour cell malignancy via enhancing net acid efflux across golgi membranes
}

\author{
Elham Khosrowabadi ${ }^{1} \cdot$ Antti Rivinoja ${ }^{2} \cdot$ Maija Risteli $^{3,4} \cdot$ Anne Tuomisto $^{4} \cdot$ Tuula Salo $^{3,4} \cdot$ Markus J. Mäkinen $^{4}$. \\ Sakari Kellokumpu' ${ }^{1}$
}

Received: 28 January 2021 / Revised: 8 June 2021 / Accepted: 25 June 2021 / Published online: 19 July 2021

(c) The Author(s) 2021

\begin{abstract}
Proper functioning of each secretory and endocytic compartment relies on its unique $\mathrm{pH}$ micro-environment that is known to be dictated by the rates of V-ATPase-mediated $\mathrm{H}^{+}$pumping and its leakage back to the cytoplasm via an elusive " $\mathrm{H}^{+}$ leak" pathway. Here, we show that this proton leak across Golgi membranes is mediated by the AE2a (SLC4A2a)-mediated bicarbonate-chloride exchange, as it is strictly dependent on bicarbonate import (in exchange for chloride export) and the expression level of the Golgi-localized AE2a anion exchanger. In the acidic Golgi lumen, imported bicarbonate anions and protons then facilitate a common buffering reaction that yields carbon dioxide and water before their egress back to the cytoplasm via diffusion or water channels. The flattened morphology of the Golgi cisternae helps this process, as their high surface-volume ratio is optimal for water and gas exchange. Interestingly, this net acid efflux pathway is often upregulated in cancers and established cancer cell lines, and responsible for their markedly elevated Golgi resting $\mathrm{pH}$ and attenuated glycosylation potential. Accordingly, AE2 knockdown in SW-48 colorectal cancer cells was able to restore these two phenomena, and at the same time, reverse their invasive and anchorage-independent growth phenotype. These findings suggest a possibility to return malignant cells to a benign state by restoring Golgi resting $\mathrm{pH}$.
\end{abstract}

Keywords Cancer $\cdot$ Invasion $\cdot$ Golgi apparatus $\cdot$ Glycosylation $\cdot$ Proton leak $\cdot$ Net acid efflux homeostasis

$\begin{array}{ll}\text { Abbreviations } \\ \text { GlcNAc } & N \text {-acetylglucosamine } \\ \text { GalNAc } & N \text {-acetylgalactosamine } \\ \text { Gal } & \text { Galactose } \\ \text { Man } & \text { Mannose } \\ \text { Fuc } & \text { Fucose }\end{array}$

Elham Khosrowabadi

elham.khosrowabadi@oulu.fi

Sakari Kellokumpu

sakari.kellokumpu@oulu.fi

1 Faculty of Biochemistry and Molecular Medicine, University of Oulu (Oulun Yliopisto), Aapistie 7A, PO BOX 5400, 90014 Oulu, Finland

2 Present Address: Northern Finland Laboratory Centre, Oulu, Finland

3 Cancer and Translational Medicine Research Unit, University of Oulu, Oulu, Finland

4 Medical Research Centre, Oulu University Hospital, Oulu, Finland

\section{Introduction}

Altered cellular metabolism, tumour acidosis, and aberrant glycosylation are all hallmarks of cancers and contribute to tumorigenesis and its progression by various means [1-4] Cancer-associated glycosylation changes most often include increased branching and/or fucosylation of N-linked glycans, synthesis of truncated mucin-type O-glycans, increased sialylation and decreased sulphation of glycosaminoglycans such as heparan sulphate [5]. Because cell-surface glycans regulate a vast number of different cell-cell and cell-matrix interactions [6,7], their alterations can modulate a variety of basic cellular functions, including inflammatory responses, immune evasion, apoptosis, cell attachment as well as cancer cell dissemination, motility, invasion, and metastasis [8-12].

Despite most cell surface glycans (collectively known as the glycocalyx) are made in the Golgi apparatus by the consecutive actions of Golgi-resident glycosyltransferases, the mechanistic details behind cancer-associated glycosylation changes are incompletely understood. Potential causes include altered expression of glycosyltransferases, their mislocalization, loss of catalytic activity, 
A ${ }_{\mathrm{GM} 130}$
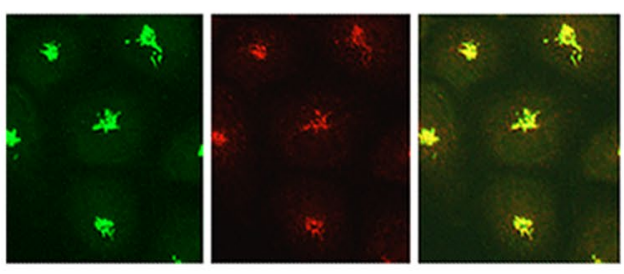

$\overline{10 \mu \mathrm{m}}$
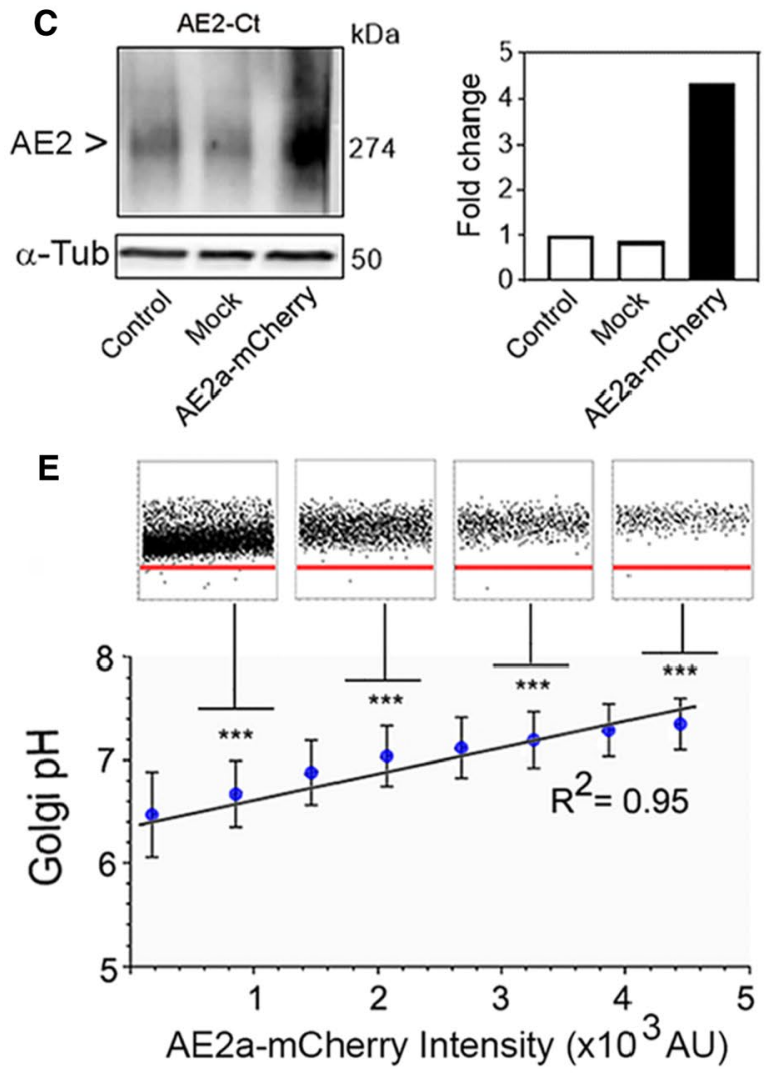
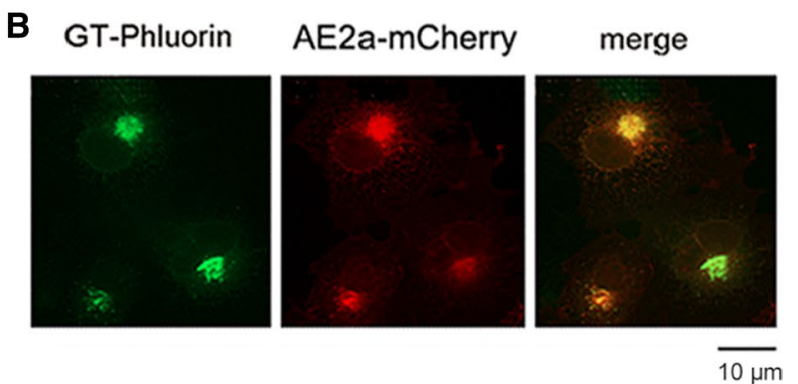

D

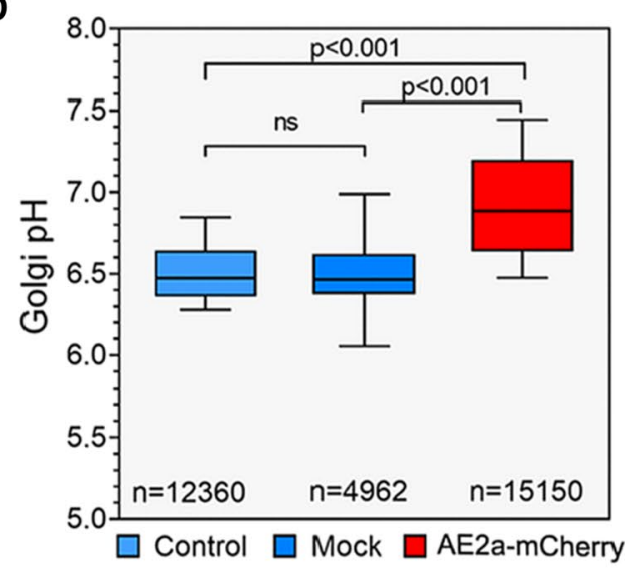

F

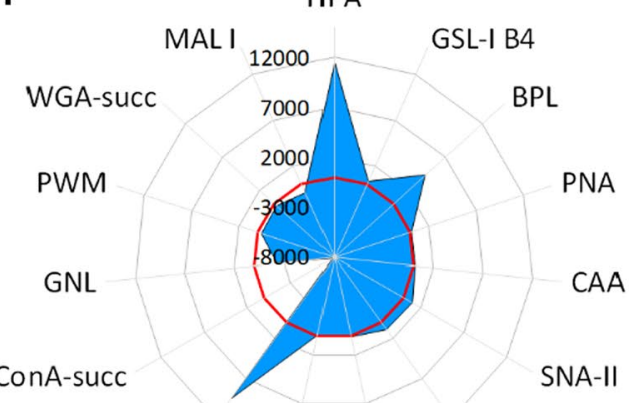

AAL SSA SJA

Fold Change

G

Gal $\beta(1,3)$ GalNAc, GaINAc GalB(1,3)GalNAc

GalNAc

GalNAC $=\mathrm{LaC}>\mathrm{Gal}$

$\alpha-/ \beta-G a l N A c$, Gal

GalNAC > Gal

GalNAc (Tn antigen)

Fuca $(1,6)$ GlcNAc (core Fuc)

$\alpha \mathrm{Man}>\alpha \mathrm{Glc}>\alpha \mathrm{Gl} \mathrm{cNAc}$

Mana(1,3)Man

$\beta(1,4)$-linked (GlcNAc)n, N-acetyllactosamine $[\operatorname{GlcNAC} \beta(1,4)] 3>[\operatorname{GlcNAC} \beta(1,4)] 2>\operatorname{GlcNAC} \gg \mathrm{Neu} 5 A c$ Neu5Ac $\alpha(2,3)$ Gal $\beta(1,4)$ GIcNAC

\section{$0 \quad 1$}

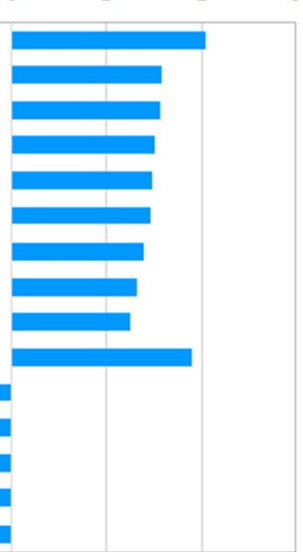

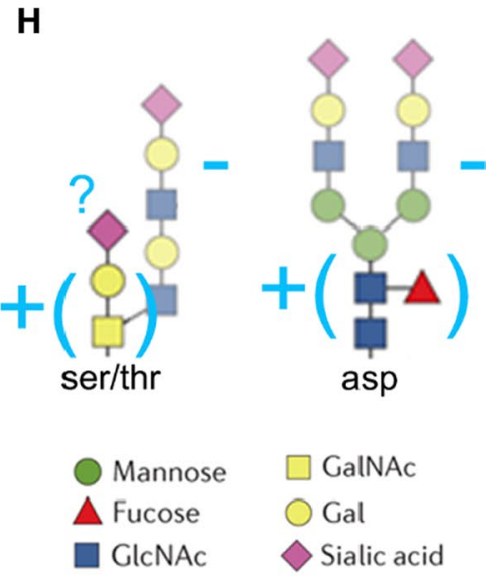


४Fig. 1 AE2a overexpression in COS-7 cells alters Golgi resting $\mathrm{pH}$ and its glycosylation potential. A Immunofluorescence microscopy of the endogenous AE2a protein and its co-localization with the Golgi marker (anti-GM130) in COS-7 cells. B Fluorescence microscopy of COS-7 cells transfected with the GT-pHluorin- and AE2a-mCherryencoding plasmids. The merged figure shows their co-localization in the Golgi. C Quantification of the AE2a-mCherry protein level in wild-type COS-7 cells (control), in mock-transfected cells, and AE2a-mCherry expressing cells. The protein was visualized after Blue Native-PAGE (BN-PAGE) by immuno-blotting with the antiAE2Ct antibody. D Ratiometric Golgi $\mathrm{pH}$ measurements in wild type, mock-transfected, or AE2a-mCherry (red) expressing COS-7 cells. AE2a-mCherry overexpressing cells were selected using the Operetta TM build-in software using the mCherry tag as a marker. In the box blot analysis, the whiskers indicate 10th to 90th percentiles; $n=$ number of cells used for analyses. E Regression analysis between Golgi resting $\mathrm{pH}$ and AE2a-mCherry expression level. Single-cell data points (dots) were classified into eight equal classes based on AE2a-mCherry intensity (200-5000 AU units, 600 AU units/class), and plotted against the Golgi resting $\mathrm{pH}$. Single-cell data points are shown for every second class. The red line ( $\mathrm{pH}$ 6.0) is added to help comparison. The means ( $\pm \mathrm{SD}, n>2000$ cells) were used to obtain the fitted regression line and its coefficient $\left(R^{2}=0.95\right)$. F Lectin binding differences between AE2a-mCherry overexpressing COS-7 cells and mock-transfected control cells. Total binding intensities (Fig $\mathrm{S} 1 \mathrm{C})$ were used to calculate the means $( \pm \mathrm{SD}, n=6)$ to select statistically significant $(p<0.05)$ changes between the cells. A two-tailed student's $t$ test was used for statistical analysis. The means were then subtracted from each other (AE2a-mCherry minus control) to get the subtracted fingerprint shown as a radar plot. The red-colored ring denotes zero lines (no difference). G A bar graph showing significant differences $(\mathbf{F})$ as fold changes. The glycotopes specific for each lectin are listed in a clockwise manner starting from the HPA lectin. $\mathbf{H}$ A cartoon that illustrates main $\mathrm{N}$ - and $\mathrm{O}$-glycan differences between AE2a-mCherry overexpressing cells and mock-transfected controls

and inability to form functionally relevant complexes in the Golgi $[13,14]$. Moreover, previous work from our laboratory suggests that Golgi resting $\mathrm{pH}$ in cancer cells is abnormally high [15] and that $\mathrm{pH}$ gradient dissipating compounds (chloroquine, ammonium chloride) can induce cancer-associated glycosylation changes in normal cells and lead to mistargeting of apical glycoproteins in epithelial cells [16-18].

Normally, Golgi acidity increases along the cis-trans axis from pH 6.7 (cis-Golgi) to $\mathrm{pH} 6.5$ (medial-Golgi), reaching $\mathrm{pH} 6.3$ at the trans-Golgi and $\mathrm{pH} 6.0$ in the trans-Golgi network, TGN $[19,20]$. It is set mainly by three main ion transport systems: the vacuolar (V)-ATPase (that pumps protons to Golgi lumen), a chloride channel (the GPHR or the GOLAC) that by importing $\mathrm{Cl}^{-}$prevent a build-up of membrane potential brought about otherwise by proton pumping, and a proton leak "channel" that allows the escape of protons back to the cytoplasm across Golgi membranes [21-24]. Of these, the proton leak pathway may be the most important one for setting organelle resting $\mathrm{pH}$ or "set point", because its rate has been shown to decrease along the secretory pathway (ER, Golgi, secretory vesicles) concomitantly with their resting $\mathrm{pH}$ [23].
While both the V-ATPase and the GPHR protein are well characterized at the molecular level, the identity of the net acid efflux pathway remains an enigma. Previous physiological measurements have suggested that net acid (proton) efflux across Golgi membranes is voltage-sensitive and inhibited by $\mathrm{Zn}^{2+}$, suggesting the involvement of a regulated "channel" [24]. Other studies have proposed that proton leak involves NHE7 and NHE8 $\mathrm{Na}^{+} / \mathrm{H}^{+}$exchangers [25]. However, a recent study shows that these exchangers act as acid loaders, and not as acid extruders, in the Golgi $[26,27]$. The AE2a (SLC4A2a) bicarbonate-chloride exchanger variant that is expressed in the Golgi membranes in a variety of cell types [28], could also contribute to Golgi resting $\mathrm{pH}$ either by importing or exporting $\mathrm{HCO}_{3}{ }^{-}$to or from the Golgi lumen. In support of this, all the members of this $\mathrm{Na}^{+}$-independent $\mathrm{Cl}^{-/} \mathrm{HCO}_{3}{ }^{-}$exchanger gene family (SLC4A1-4 or AE1-AE4) are known to mediate a diisothiocyanatostilbene-2,2-disulfonate (DIDS)-sensitive, electroneutral and obligatory one-to-one exchange of chloride for bicarbonate $[29,30]$. Thereby, they can regulate intracellular $\mathrm{pH}(\mathrm{pHi})$, cell volume, and chloride concentration in the cells. Of these, the AE2 isoform is detected in nearly all tissues and cells examined, and therefore, is said to have a "housekeeping" role in the cells. Consistent with this, AE2 knockout in mice causes a severe phenotype, as $\mathrm{AE} 2^{-/-}$mice often die either before or at weaning [31].

AE2 has at least 3 known variant polypeptides (AE2a-c) which differ from each other by their variable $\mathrm{N}$-terminal domains [29, 30]. Both the N- and C-termini of the AE2 variant polypeptides are known to be cytoplasmic and can interact with proteins that regulate either the activity or its subcellular localization in the cells. The cytoplasmic C-terminal tail in turn has been shown to interact with carbonic anhydrase II (or IV), an enzyme in the cytoplasm that produces bicarbonate anions (and protons) for transport [32,33]. This interaction was found to enhance $\mathrm{AE}$ anion transport activity as well as the catalytic activity of the CAII [34], suggesting that they form a "transport metabolon". However, its existence was later challenged [35], and therefore needs to be formally verified. The $\mathrm{N}$-terminus of the AE2a (the longest $\mathrm{N}$-terminal variant) in turn has been shown to bind ANK195, a Golgi-specific ankyrin isoform [36] that links the AE2ANK195 complex to $\beta$ III spectrin-based Golgi membrane skeleton [37]. Thus, this interaction likely is responsible for the localization of the AE2a variant in the Golgi.

To find out whether the AE2a variant, indeed, contributes to Golgi resting $\mathrm{pH}$, we measured directly its effect on Golgi resting $\mathrm{pH}$ in COS-7 cells that express an endogenous AE2a variant in the Golgi $[28,36]$, in cells that overexpress it, or in cells in which the AE2a variant was knocked down with AE2-specific shRNAs. Previously, we have shown that COS-7 cells do not express other AE2 variants at a detectable level in the Golgi or the plasma membrane [28]. By 
using ratiometric and Golgi-targeted pHluorin as the probe [38], we now show that the AE2a variant regulates Golgi resting $\mathrm{pH}$ by facilitating net acid efflux across Golgi membranes via the well-known chemical buffering reaction that yields carbon dioxide and water from luminal bicarbonate anions and protons. The functional relevance of this pathway was also verified by showing that it is often upregulated in cancers and established cancer cell lines, consistent with their elevated Golgi resting $\mathrm{pH}$ and altered glycosylation status. Intriguingly, we also show that AE2 knockdown in one of these cell lines (SW-48) was not only able to restore an acidic Golgi resting $\mathrm{pH}$ and its glycosylation potential, but also to reverse their invasive and anchorage-independent growth phenotype. Our lectin microarray glycan profiling also uncovered two potential glycotopes that may govern this phenotypic change between the cells.

\section{Results}

\section{AE2a expression level alters Golgi resting $\mathrm{pH}$ and its glycosylation potential}

We chose COS-7 cells as target cells mainly because they endogenously express the AE2a variant in the Golgi and do not express other AE2 transcripts or variant proteins at detectable levels at the plasma membrane $[28,36]$. The cells also display a normally acidic ( $\mathrm{pH}$ 6.3-6.5) Golgi resting $\mathrm{pH}$ [18]. We confirmed this by both immunofluorescence (Fig. 1A) and immunogold cryo-electron microscopy (Fig. S1A). Staining of COS-7 cells with an affinity-purified anti-C-terminal AE2-antibody that recognizes all the AE2 variants confirmed an almost exclusive localization of the AE2a in the medial/trans-Golgi cisternae and the trans-Golgi network (TGN).

To investigate whether the AE2a variant regulates Golgi resting $\mathrm{pH}$, we determined Golgi resting $\mathrm{pH}$ in live wildtype COS-7 cells and in cells that overexpress the same variant. By using the medial/trans-Golgi-targeted pHluorin (GT-pHluorin, Fig. 1B) as a probe. Ratiometric measurements showed that AE2a overexpression increased significantly ( $p<0.001$ ) Golgi resting $\mathrm{pH}$ by $0.5 \mathrm{pH}$ units (from $\mathrm{pH}$ 6.4 to 6.9 ; Fig. 1D) when compared to wild type or mocktransfected controls (Fig. 1C). Single-cell data analyses also revealed a strict correlation $\left(R^{2}=0.95\right)$ between the AE2a expression level and the Golgi resting pH (Fig. 1E).

Since Golgi acidity is known to be important for proper glycosylation $[17,18]$, we next assessed how AE2a overexpression alters the COS-7 cell glycosylation profile. Lectin microarray glycan profiling (Fig. S1B) showed that out of the 43 lectins, 15 showed significant $(p<0.05)$ changes in their binding to their relevant glycotopes (Fig. 1F). The main changes included upregulation of truncated O-glycan glycotopes GalNAc (the Tn-antigen) and Gal $\beta(1,3)$-GalNAc (the T-antigen) as well as core-fucosylated $\mathrm{N}$-glycans (Fig. 1G). Other N-glycan recognizing lectins, instead, showed downregulation of terminal mannose-, $\mathrm{N}$-acetylglucosamine-, galactose- and $\alpha(2,3)$-linked sialic acid-containing $\mathrm{N}$-glycans. Collectively, these findings suggest that the elevated Golgi resting $\mathrm{pH}$ in AE2a overexpressing cells impairs glycosylation either by enhancing the synthesis of O-glycan and N-glycan "core" structures or by attenuating their elongation (Fig. 1H). Since they are normally masked by further glycosylation in the Golgi $[4,5,7,12]$, the latter possibility is more likely.

Knockdown of the endogenous AE2a protein in COS-7 cells with AE2-specific shRNAs provided further support for its role in Golgi pH regulation. For knockdown, we used a doxycycline inducible SMART ${ }^{\mathrm{TM}}$ vector system, because it allows adjustment of the knockdown efficiency and thus, preservation of cell viability, in contrast to its complete knockout in mice [31]. In stably transfected cells, all three AE2-specific shRNAs used (Table S1) diminished the level of the AE2a protein by $10-60 \%$ depending on the Doxycycline concentration used (Fig. S1C). They also decreased Golgi resting $\mathrm{pH}$ by $\sim 0.2 \mathrm{pH}$ units in induced cells, when compared to non-induced controls or wild type or scrambled shRNA with or without the induction (Fig. 2A). Single-cell data analyses in shRNA\#1 knockdown cells also confirmed that the Golgi resting $\mathrm{pH}$ was decreased uniformly in most cells of this cell population (Fig. 2B).

\section{AE2a knockdown also altered COS-7 cell glycosylation potential}

Lectin microarray glycan profiles (Fig. S1D) showed that these changes, in general, were opposite to those detected upon AE2a overexpression (Fig. 2C). Only two lectins (succinylated ConA and GNL) displayed significantly lower binding of mannose-type N-glycans in both AE2a knockdown and AE2a overexpressing cells. Other lectins (Fig. 2D) also displayed significantly diminished binding of their specific glycotopes. The fold changes, however, did not exceed more than 1.5-fold (Fig. 2E), except in the case of the two mannose-type $\mathrm{N}$-glycan specific lectins (succinylated ConA and GNL) which exhibited roughly twofold lower binding of their glycotopes (Fig. 2E). These findings indicated that not only AE2a overexpression but also its knockdown in COS-7 cells, slightly impairs glycosylation of $\mathrm{N}$-and O-glycans, reflecting their opposite effects on Golgi $\mathrm{pH}$ and its extent. The main differences detected between these two cell types suggest that AE2a knockdown may specifically inhibit $\mathrm{O}$-glycan synthesis and $\mathrm{N}$-glycan branching, while AE2a overexpression affects their elongation. More detailed glycan analyses are needed, however, to clarify this issue. 


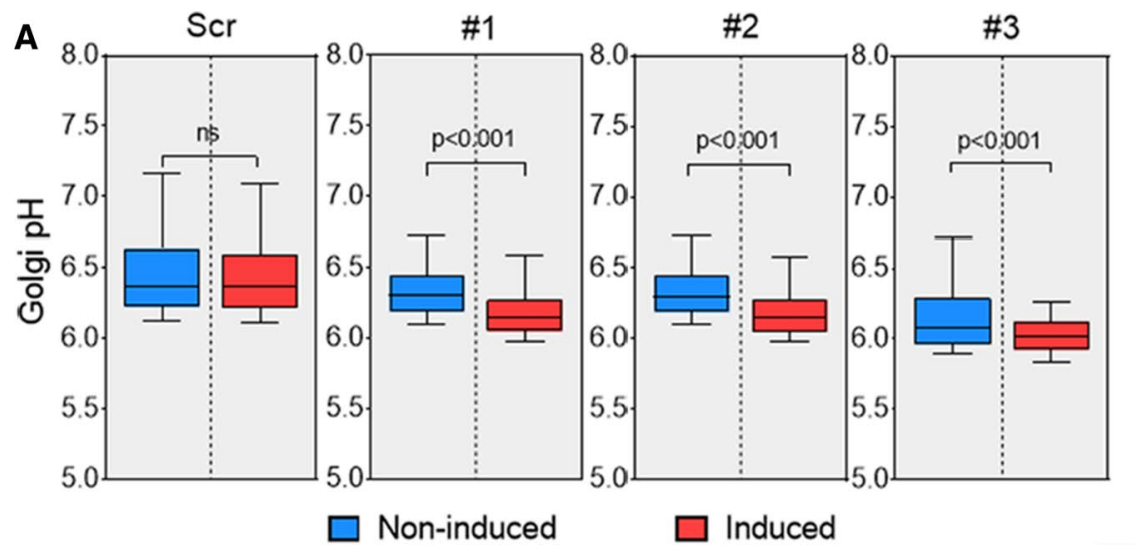

C

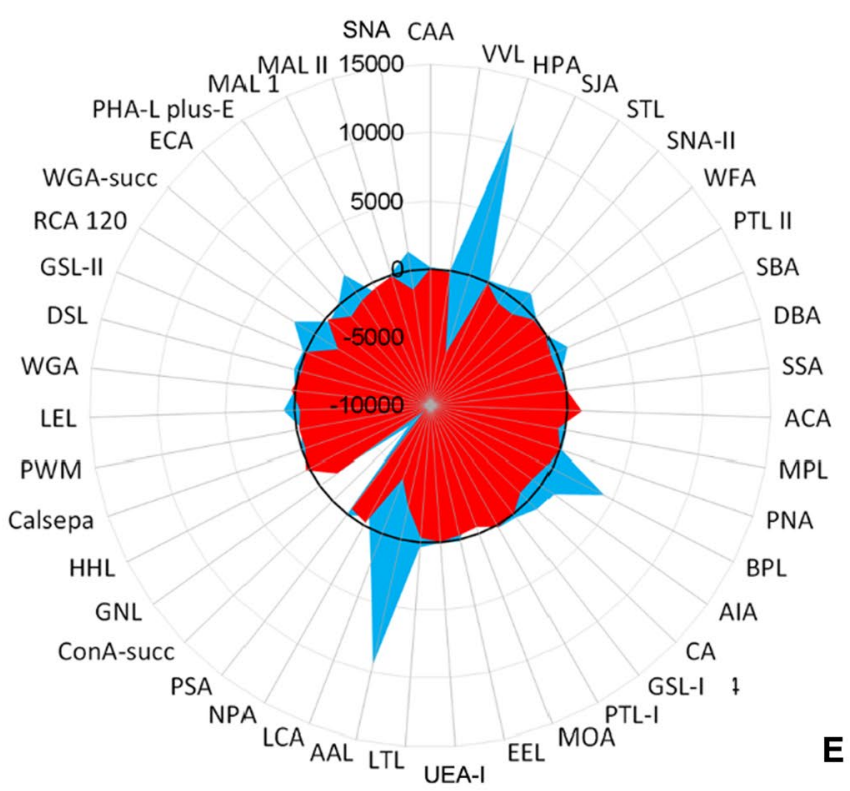

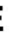

D

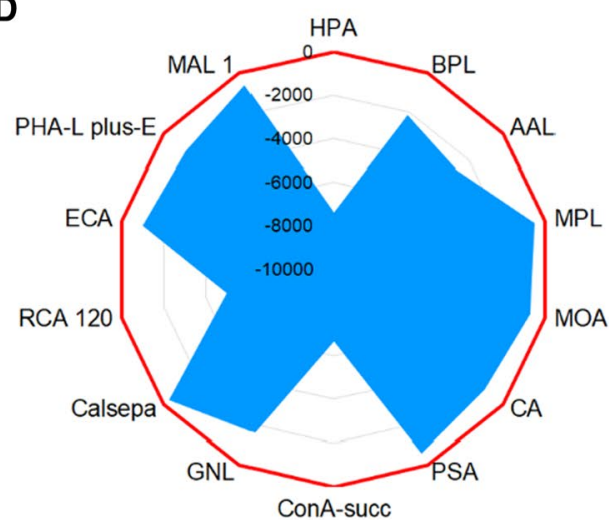

- AE2 KD-CTRL (Non-Ind.)
- AE2a KD vs CTRL (Non-ind.)

AE2a plus vs CTRL (Mock)
GalNAc

Galß $(1,3)$ GalNAc, GalNAc Fuca $(1,6)$ GIcNAc (core Fuc) Gal $\beta(1,3)$ GalNAc > Gal Gala(1,3)Gal, Blood group B Lac $>$ GalNAc $>$ Gal aMan, $a \mathrm{Glc}$

$a$ Man $>a G l c>a G I c N A c$

Mana $(1,3)$ Man

Man, High Man

Gal $\beta(1,4)$ GlcNAc

Gal3(1,4)GlcNAC, LacNAc > Lac > GalNAc, Gal Gal, Complex triantennary N-glycans Neu5Aca $(2,3)$ Gal $\beta(1,4)$ GlcNAc

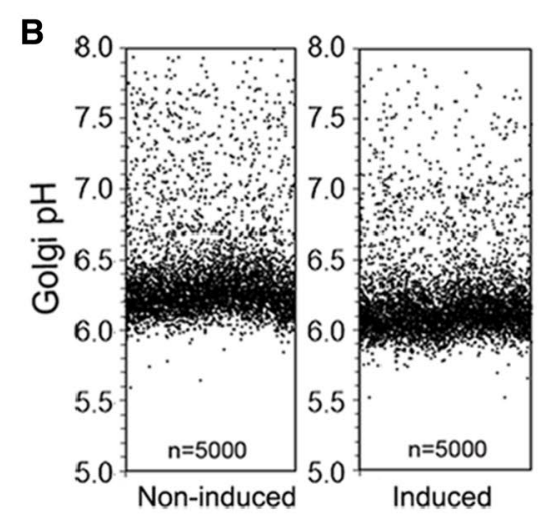



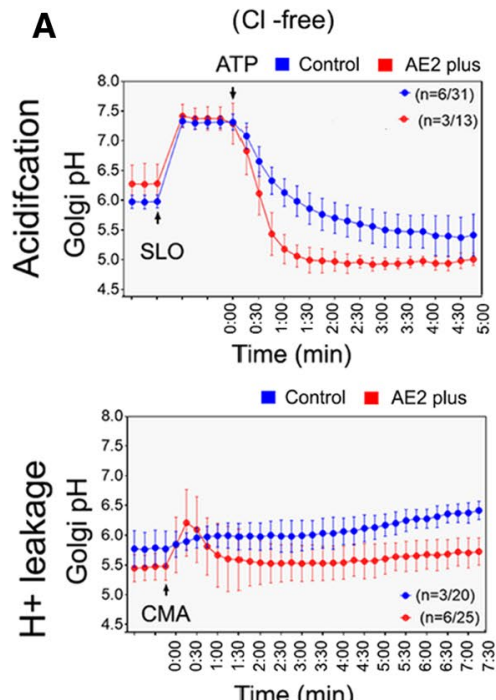

Time (min)

Chloride free (130mM K-gluc./30mM Na gluc.)

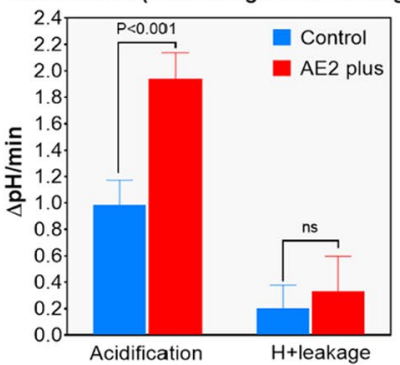

D
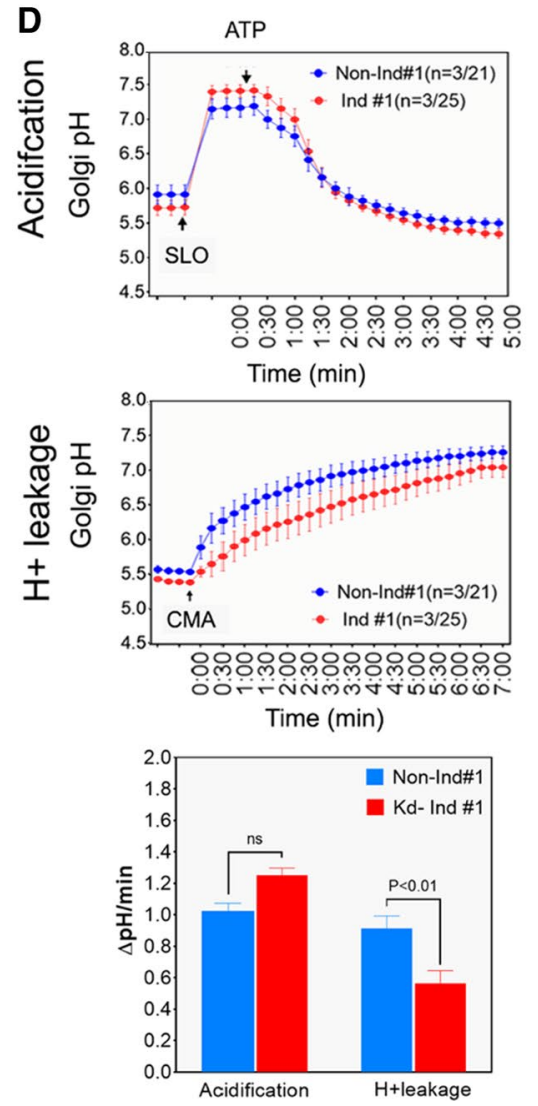

B

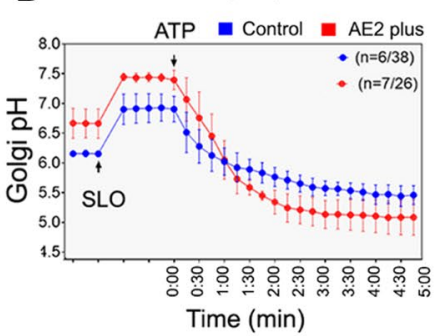

C (KC//HCO3-)
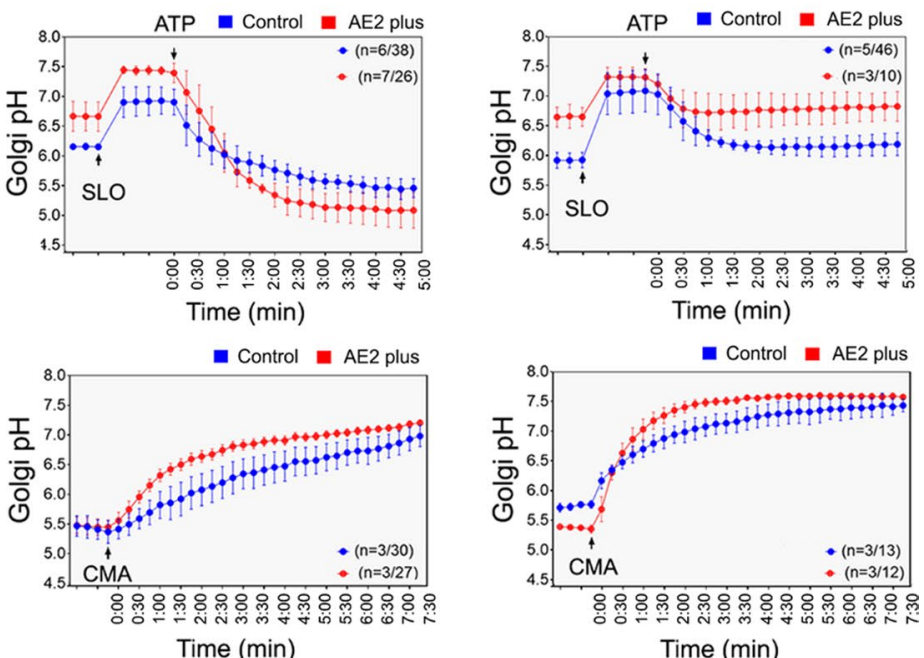

- Control a AE2 plus
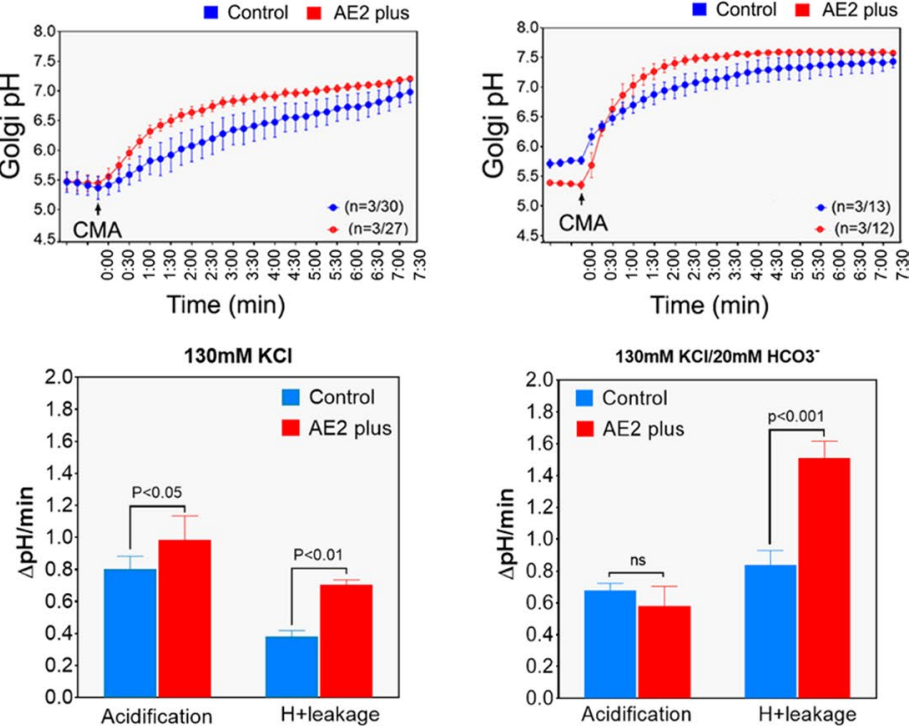

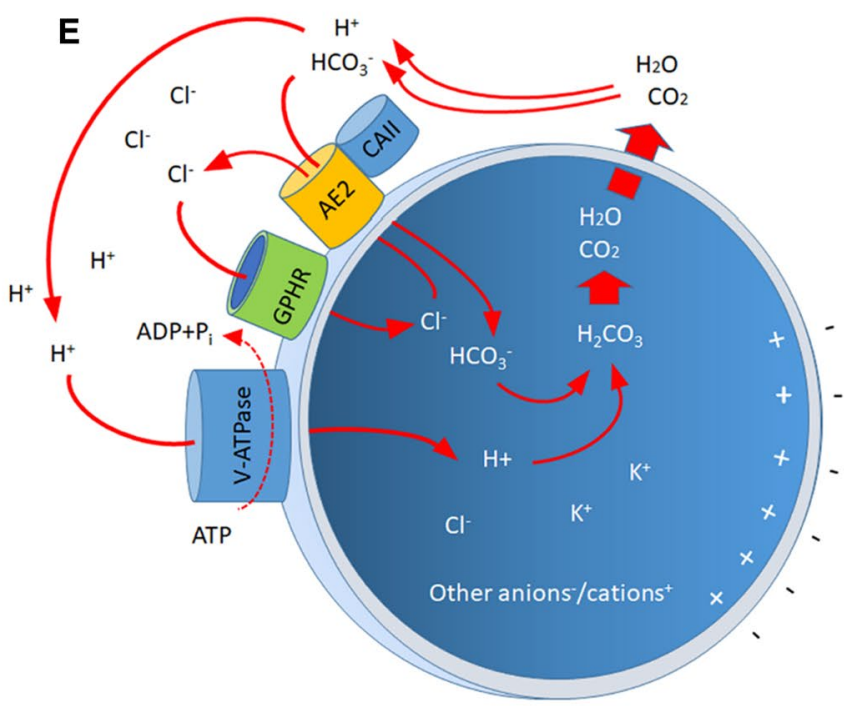


४Fig. 3 AE2a alters Golgi resting pH via facilitating net acid efflux across Golgi membranes. Cells transfected with GT-pHluorin plasmid, either with or without the AE2a-mCherry plasmid, were permeabilized with SLO before ratio-imaging of the cells. Cells were kept in different bath solutions during the experiment: $\mathbf{A}$ no $\mathrm{Cl}^{-}$nor $\mathrm{HCO}_{3}{ }^{-}, \mathbf{B}$ only $\mathrm{Cl}^{-}$(no $\mathrm{HCO}_{3}{ }^{-}$) and $\mathbf{C}$ both $\mathrm{Cl}^{-}$and $\mathrm{HCO}_{3}{ }^{-}$. Arrows denote the addition of SLO, ATP, or CMA to the bath medium. The obtained ratios were transformed to $\mathrm{pH}$ values (mean $\pm \mathrm{SD}, \mathrm{n} \geq 3$ /total number of cells used in the experiments) using an equation obtained from the calibration standard curve. The $\mathrm{pH}$ values were then plotted against time. The bars (bottom panels) depict the initial acidification and leakage rates $(\Delta \mathrm{pH} / \mathrm{min})$ that were calculated from the fitted curves in each case. D Golgi acidification and net acid efflux rates in AE2 knockdown (induced) COS-7 cells and in control cells (non-induced) carrying the same plasmid (shRNA\#1). Golgi acidification rate measurements were done in the absence (top) of $20 \mathrm{mM}$ bicarbonate to be able to compare the maximal proton pumping rates by the V-ATPase. Proton leak rate measurements in control and AE2 $\mathrm{KD}$ cells. The $\mathrm{pH}$ values as well as the initial Golgi acidification and net acid efflux rates $(\Delta \mathrm{pH} / \mathrm{min})$ were obtained as above and plotted against time. $20 \mathrm{mM}$ bicarbonate was present in the bath solution to allow maximal net acid efflux rate from the Golgi lumen. $\mathbf{E}$ The deduced model describing the AE2a-mediated net acid efflux pathway across the Golgi membranes. The main ions as well as their corresponding transporters are shown

\section{AE2a-mediated bicarbonate import enhances net acid efflux across the Golgi membranes}

Next, we carried out Golgi acidification and proton-leakage rate measurements in COS-7 cells to assess why AE2a overexpression increases Golgi resting $\mathrm{pH}$, and knockdown decreases it. To accomplish this, both control cells carrying an empty vector (mock-transfected cells) or cells overexpressing the AE2a variant (AE2plus cells) were transfected with the GT-pHluorin plasmid. One day later, the plasma membrane of the cells was first permeabilized with streptolysin O (SLO) [39] to allow controlled removal or addition of ATP, $\mathrm{Cl}^{-}$or $\mathrm{HCO}_{3}{ }^{-}$to the cytoplasm. Golgi $\mathrm{pH}$ changes were then followed by ratiometric imaging of the selected Golgi regions. In $\mathrm{Cl}^{-} / \mathrm{HCO}_{3}{ }^{-}$free bath medium (to minimize AE2a anion exchange activity), the addition of excess ATP $(10 \mathrm{mM})$ resulted in marked acidification of the Golgi lumen (Fig. 3A top panel) before it plateaued at pH 5.0-5.5 both in AE2a overexpressing and mock-transfected control cells, respectively. The calculated initial acidification rates $(\Delta \mathrm{pH} / \mathrm{min}$ ) were 1.0 and $1.9 \mathrm{pH}$ units/min (Fig. 3A bottom panel), i.e. significantly higher in AE2 plus cells than in control cells. Proton "leakage" or efflux rates measured after blocking the V-ATPase with $1 \mu \mathrm{M}$ Concanamycin A (CMA) further showed that they were low, and the initial leakage rates did not exceed $0.35 \mathrm{pH}$ units $/ \mathrm{min}$ in either case (Fig. 3A, middle and bottom panels).

When $\mathrm{Cl}^{-}$anions were added to the bath medium (by replacing $\mathrm{KCl}$ with $\mathrm{K}$-gluconate), Golgi acidification rate in AE2a overexpressing cells was still significantly higher than that of control cells ( 0.8 vs. $1.0 \mathrm{pH}$ units/min, (Fig. 3B top and bottom panels), although $\mathrm{Cl}^{-}$addition decreased the initial $\Delta \mathrm{pH} / \mathrm{min}$ from $1.9 \Delta \mathrm{pH} / \mathrm{min}$ (no chloride) to 1.2 $\Delta \mathrm{pH} / \mathrm{min}$ (with chloride, Fig. 3B bottom panel). In contrast, the presence of $\mathrm{Cl}^{-}$in the bath medium increased net acid efflux rates (Fig. 3B, middle panel) in both control and AE2a overexpressing cells by $\sim$ twofold when compared to the rates in $\mathrm{Cl}^{-}$-free bath medium (Fig. 3B, bottom panel), probably due to endogenous activity of carbonic anhydrase II (CA II) and the production of $\mathrm{HCO}_{3}^{-}$. In addition, the $\mathrm{H}^{+}$leakage rate was significantly higher in AE2a overexpressing cells than in mock-transfected control cells (Fig. 3B, middle and bottom panels).

Addition of $\mathrm{Cl}^{-}$and $\mathrm{HCO}_{3}{ }^{-}$to the bat medium slowed down Golgi acidification in both control and AE2a overexpressing cells (Fig. 3C). Golgi luminal $\mathrm{pH}$ also plateaued at pH 6.3 (control cells) or pH 6.7 (AE2a overexpressing cells). These changes coincided with markedly faster net acid efflux rates in both cell types (Fig. 3C middle and bottom panels). AE2a overexpressing cells also displayed a significantly higher leak rate than mock-transfected control cells, suggesting that net acid efflux across Golgi membranes is strictly dependent on the presence of chloride and bicarbonate anions in the bath media as well as the expression level of the AE2a protein in the Golgi membranes of the cells. In support of this view, AE2a knockdown cells displayed a significantly lower net acid efflux rate than did non-induced control cells (Fig. 3D, middle and bottom panels) while their Golgi acidification rate was not affected. In addition, when cells were bathed in different bicarbonate-free buffer solutions (containing SLO and adjusted to $\mathrm{pH} 6, \mathrm{pH} 7, \mathrm{pH} 8$, respectively), we did not detect marked differences in the Golgi resting $\mathrm{pH}$ between the cells (Fig. S2A). On the other hand, cultivation of intact COS-7 and HeLa cells in $40 \mathrm{mM}$ bicarbonate (normally $20 \mathrm{mM}$ ) increased significantly $(p<0.001)$ Golgi resting $\mathrm{pH}$ in the cells (Fig. S2B).

To evaluate whether the model is feasible also electrochemically, we calculated electrochemical driving forces for AE2a-mediated chloride-bicarbonate exchange. Thus, the V-ATPase generated $\mathrm{H}^{+}$gradient ( $\sim 1 \mathrm{pH}$ unit) across Golgi membrane creates a $+61.5 \mathrm{mV}$ Nernst potential that at $\mathrm{pH}_{\mathrm{G}}$ 6.0 and $\mathrm{pH}_{\mathrm{i}} 7.0$ corresponds to $-61.5 \mathrm{mV}$ electrochemical driving force for either influx of negative ions $\left(\mathrm{Cl}^{-}\right)$or efflux of positive ions $\left(\mathrm{K}^{+}, \mathrm{Na}^{+}\right)$or both. These ion fluxes will then counteract to balance the "proton motive force", consistent with the notion that membrane potential across Golgi membranes is non-existent [24]. At equilibrium (107 mM $\left.\left[\mathrm{K}^{+}\right]_{\mathrm{G}} ; 140 \mathrm{mM}\left[\mathrm{K}^{+}\right]_{\mathrm{i}},[24]\right)$, Nernst equation calculations indicated that $\mathrm{K}^{+}$efflux would equal an equilibrium potential of $-7 \mathrm{mV}$. Assuming that $\mathrm{Cl}^{-}$influx will balance the rest $(-54 \mathrm{mV})$ of the " $\mathrm{H}^{+}$motive force", $[\mathrm{Cl}-]_{\mathrm{G}}$ would equal to $\sim 0.5 \mathrm{mM}$ when $\left[\mathrm{Cl}^{-}\right]_{\mathrm{i}}$ is set to $4 \mathrm{mM}$ [43]. Due to continuous proton pumping [24] and the consumption of $\mathrm{HCO}_{3}{ }^{-}$anions for Golgi buffering, its concentration in the 


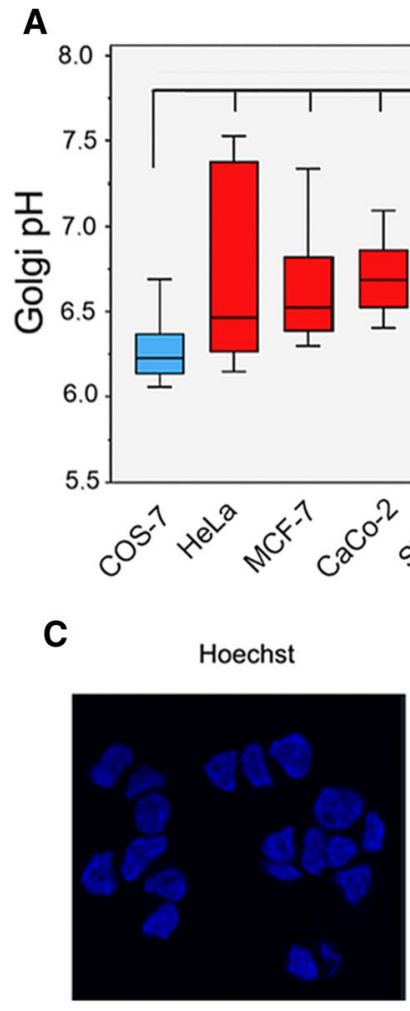

D

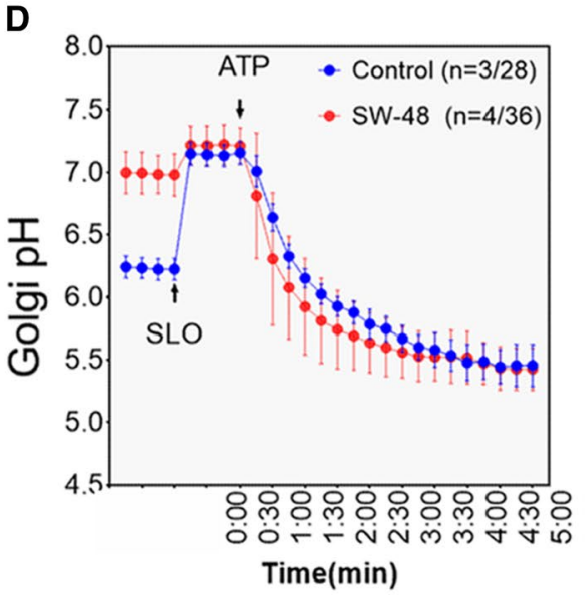

F

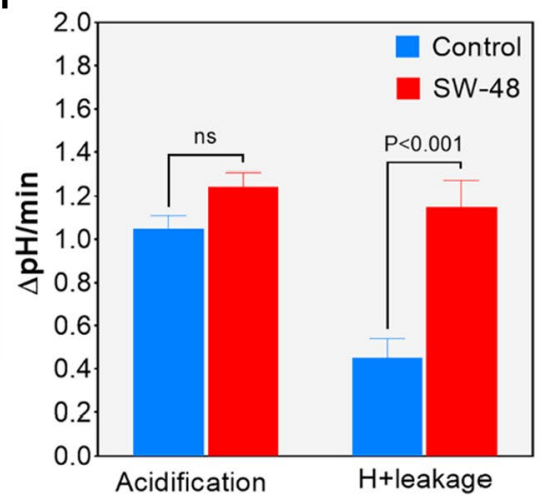

B

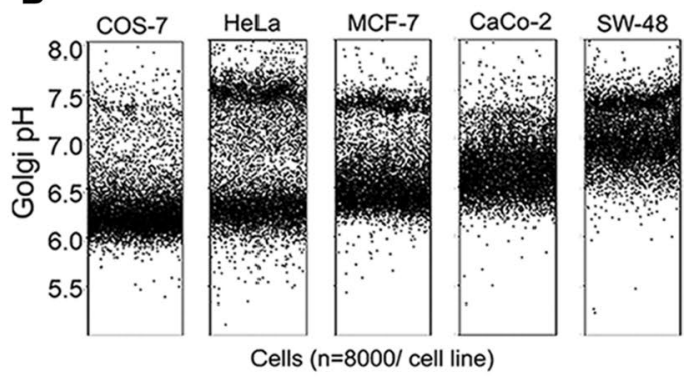

GM130

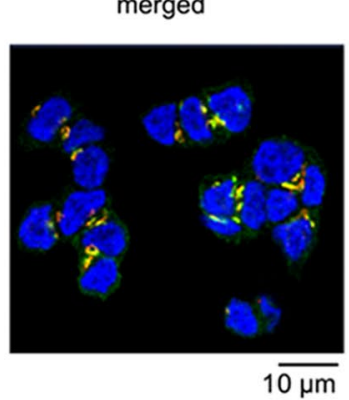

E

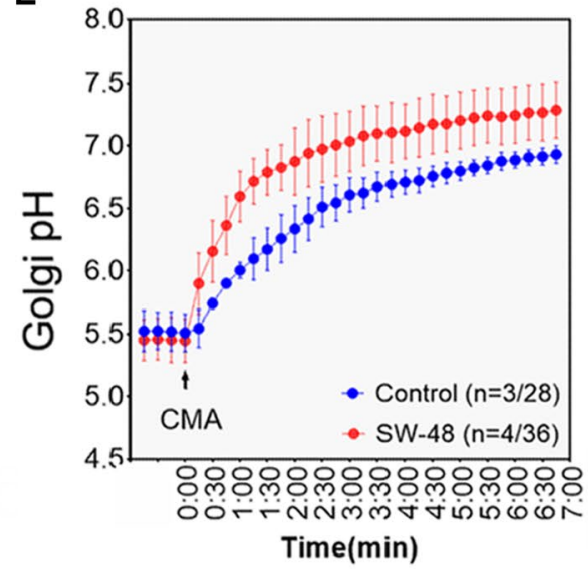

G

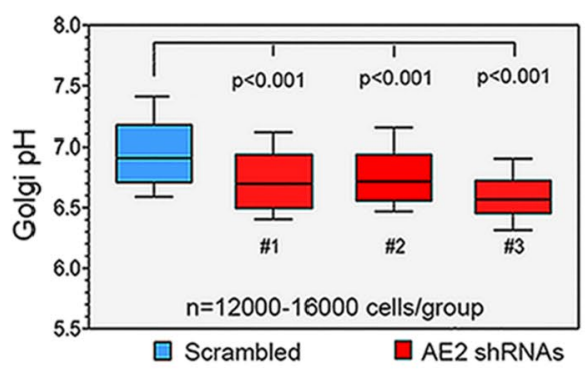


4Fig. 4 AE2 upregulation in cancer cells is responsible for their elevated Golgi resting $\mathrm{pH}$. A Golgi resting $\mathrm{pH}$ in different cancer cell types in comparison to non-malignant control cells. Golgi resting $\mathrm{pH}$ in each cell type was determined as above (Fig. 1) using the GTpHluorin as a probe. The values are shown using box plots. Whiskers above and below each box indicate 10th to 90th percentiles. B Singlecell analysis of the Golgi resting $\mathrm{pH}$ in the four depicted cancer cell types and COS-7 cells. Golgi pH values from 8000 cells in each case were blotted individually for each cell type. Note the two distinct cell populations which differ in the Golgi resting $\mathrm{pH}$ in three cell lines. C Immunofluorescence microscopy of the endogenous AE2 protein showing its localization in the Golgi and at the plasma membrane (faint circle outside the nucleus) of SW-48 cells. Fixed cells were costained with the anti-AE2Ct antibody and with a Golgi marker antibody (GM130). Golgi acidification (D) and net acid efflux (E) rates in SW-48 cells. The experimental set-up is identical to that described in Fig. 3. The calculated initial acidification and leakage rates $(\Delta \mathrm{pH} /$ min) are also shown (F). G Golgi resting $\mathrm{pH}$ in SW-48 cells after AE2 knockdown. Stably transfected SW-48 cells carrying either the shRNA\#3 or the control plasmid (scrambled shRNA) were induced for 3 days using $100 \mathrm{ng} / \mathrm{ml}$ of Doxycycline. Golgi resting $\mathrm{pH}$ values were then determined as above. The whiskers above and below the box indicate 10th to 90 th percentiles

Golgi lumen will remain low, compared to its concentration in the cytoplasm (12 $\mathrm{mM} \mathrm{HCO}_{3}{ }^{-}$, [43]). Therefore, a high $\left[\mathrm{HCO}_{3}{ }^{-}\right]$gradient between the cytoplasm and the Golgi is expected to favour AE2a-mediated bicarbonate import in exchange for chloride export against its smaller concentration gradient across Golgi membranes, in accord with the model.

Based on these observations, we suggest a model (Fig. 3E and supplementary video) in which AE2amediated bicarbonate import (in exchange for luminal chloride) facilitates net acid efflux across Golgi membranes via the well-known bicarbonate buffering reaction $\left(\mathrm{H}^{+}+\mathrm{HCO}_{3}{ }^{-}>\mathrm{H}_{2} \mathrm{CO}_{3}>\mathrm{H}_{2} \mathrm{O}+\mathrm{CO}_{2}\right.$, [40]) that produces carbon dioxide and water from luminal bicarbonate anions and protons before their egress to the cytoplasm via diffusion or aquaporin water channels [41, 42]. Their egress is likely helped by the flattened shape of the Golgi cisternae, as their high surface-to-volume ratio (as in erythrocytes) is optimal for water and gas exchange. It is perhaps also not a mere coincidence that the $\mathrm{pKa} 6.4$ of the bicarbonate-carbonic acid reaction is within the same range as the Golgi resting $\mathrm{pH}(\mathrm{pH}$ 6.7-6.0).

\section{AE2 mRNA and protein levels are often upregulated in cancers and cancer cell lines}

The Cancer Genome Atlas mRNA expression database (matched TCGA and GTEx data) analyses suggested that the AE2-mediated net acid efflux pathway may have functional relevance in cancer cells because the AE 2 mRNA is often upregulated in cancer tissues compared to matched normal tissues. Because the mRNA nor the $\mathrm{AE} 2_{\mathrm{CT}}$ antibody analyses do not discriminate between different AE2 variants
(AE2a-c), the term "AE2" will be used from here onwards. Interestingly, mRNA level analyses showed significantly $(p<0.05)$ upregulated AE2 mRNA levels in more than half (16/31) of the cancer types present in the database. Of these, six cancer types showed highly significant $(p<0.001)$ upregulation of the AE2 mRNA (Fig. S3A). Kaplan-Meier survival plots also suggested that a high AE2 mRNA expression level increases death risk by 1.6-fold (Fig. S3B). In addition to these six cancer types, analyses using only the matched TCGA as controls revealed that the AE2 mRNA is also significantly $(p<0.05)$ upregulated in colon and rectum carcinomas (Fig. S3C). Survival plots also indicated 1.3-fold and 5.4-fold increased death risk in these patients, respectively (Fig. S3D, E). Immunoblotting of AE2 protein in seven low-grade colorectal cancer tissue specimens further verified its variable expression in cancer tissues. We found that four (57\%) displayed more than 1.5-fold higher AE2 protein levels than the control tissue specimens (Fig. $\mathrm{S} 3 \mathrm{~F}$ ). In addition, immunostaining of colorectal cancer tissue sections revealed that the AE2 protein is present in the Golgi membranes but also at the plasma membrane of cancer cells (Fig. S3G). Taken together, the above in vivo findings suggested that AE2 overexpression in the Golgi and/or the plasma membrane may contribute to tumorigenesis and/or its progression at least in some cancer cell types.

\section{AE2 overexpression in SW-48 cells is responsible for their elevated Golgi resting $\mathrm{pH}$}

Immunoblotting of the AE2 protein in different cancer cell lines revealed further that the protein was also overexpressed in four out of the nine (44\%) cell lines tested (Fig. 3H). These four AE2 overexpressing cell lines (SW-48, HT-29, RCC4, and MDA-MB231) also displayed the highest Golgi resting $\mathrm{pH}$ values that ranged between $\mathrm{pH}$ 6.9-7.2 (Fig. 4A). Intriguingly, however, Golgi resting $\mathrm{pH}$ was also elevated $\left(\mathrm{pH}_{\mathrm{G}}\right.$ 6.5-6.8) in all the other cancer cell lines as well, even though they did not overexpress the AE2 protein. Statistical analyses also failed to reveal a correlation between the AE2 expression level and the Golgi resting $\mathrm{pH}$ in the cell types used $(R=0.59, p>0.05)$. Therefore, we anticipate that in cell types that express the AE2 protein at comparable or lower levels than COS-7 cells, changes in cytoplasmic $\mathrm{pH}$ or the activity of enzymes or other ion transporters contribute to Golgi resting $\mathrm{pH}$, are likely responsible for their elevated Golgi resting $\mathrm{pH}$. In addition, single-cell data analyses (Fig. 4B) demonstrated that HeLa and MCF-7 cells, in particular, display two distinct cell populations that differ in their Golgi resting $\mathrm{pH}$. Their co-existence was not associated with poor cell survival or cell death, as such cells do not resist repeated washings and media changes during the experiments. Golgi fragmentation that is typical in cancer cells (Fig. S4A) was also not the reason, as both compact 
and fragmented Golgi elements had rather similar Golgi resting $\mathrm{pH}$ values (Fig. S4B). Moreover, despite elevated Golgi resting $\mathrm{pH}, \mathrm{HeLa}$ cells have a compact Golgi (Fig. S4A and $\mathrm{S} 4 \mathrm{C})$. Instead, the co-existence of the two cell populations likely reflects adaptation to hypoxia, as exposure of MCF-7 and SW-48 cells to hypoxia $\left(5 \% \mathrm{O}_{2}\right.$ instead of $\left.16 \% \mathrm{O}_{2}\right)$ for $48 \mathrm{~h}$ decreased Golgi resting $\mathrm{pH}$ only in "high $\mathrm{pH}$ " cell population while it did not affect the "low $\mathrm{pH}$ " cell population (Fig. S4D).

To assess the role of the AE2 overexpression in more detail on tumorigenesis, we chose SW-48 colorectal cancer cells as our targets mainly because nearly all (98\%) SW-48 cells displayed markedly elevated Golgi resting pH (Fig. S4E). Most of them also bind PNA lectin (Fig. S4F), a sign of altered glycosylation. The cells were also found to contain comparable levels of ATP to COS-7 cells (Fig. S3G, $\mathrm{H})$ which should sustain proton pumping if the V-ATPase is functional in the cells. The cells also express a substantial amount of the AE2 protein in the Golgi membranes, yet the protein is detectable also at the cell surface (Fig. 4C), in line with our in vivo results (Fig. S3G). Golgi acidification and net acid efflux rate measurements in the cells revealed that the Golgi lumen was acidified at a comparable rate and extent to COS-7 cells (Fig. 4D), indicating that the V-ATPase is fully functional and therefore not responsible for their elevated Golgi resting $\mathrm{pH}$. In contrast, the net acid efflux rate (Fig. 4E, F) was significantly (by 2.6-fold) higher than that of COS-7 cells $(\Delta \mathrm{pH} 1.15 \mathrm{pH}$ units/min vs. $\Delta \mathrm{pH}$ $0.45 \mathrm{pH}$ units/min, respectively). In addition, AE2 knockdown in the cells (Fig. S5A) decreased significantly their Golgi resting pH from pH 6.9 (Scr) to 6.6 (Fig. 4G). It also decreased significantly their PNA lectin binding activity (Fig. S5B) as well as the percentage of PNA-positive cells in the cell population (Fig. S5C). AE2 knockdown also slightly elevated cytoplasmic resting $\mathrm{pH}$ in the cells (Fig. S5D), consistent with its functioning against alkaline loads [29, 30].

\section{AE2 knockdown in SW-48 cells reverses their invasive and anchorage-independent growth phenotype}

To test whether AE2 upregulation has any consequences on SW-48 cell phenotype, we first compared cell proliferation rates between wild type SW-48 (WT), AE2 knockdown cells (KD), and AE2 Scr control cells (i.e., cells that carry the scrambled shRNA construct). AE2 knockdown had no marked effect on cell proliferation rate when compared with either WT or Scr cells (Fig. 5A). Based on a scratch wound healing assay, AE2 knockdown decreased cell migration rate to roughly $50 \%$ of that found in wild-type cells (Fig. 5B, C). AE2 knockdown cells also displayed a more dispersed growth phenotype, as the cells did not form similar colonies or cell clumps as did wild-type SW-48 cells (Fig. 5D), suggesting that AE2 knockdown may alter cell-cell contacts or their interaction with the extracellular matrix.

An important feature of malignant cells is their invasiveness. Therefore, we assessed whether AE2 upregulation in SW-48 cells is associated with their invasive potential. By using an established 3D human myoma-based invasion assay [44], we found that SW-48 WT cells were highly invasive and showed invasion foci inside the myoma tissue at a 200 to $400 \mu \mathrm{m}$ distance from the seeded top cell layer (Fig. 6A). Similar foci were also seen with SW-48 Scr cells with or without prior doxycycline induction (Fig. 6B, C). In contrast, no invasion foci were detected induced by AE2 knockdown cells, albeit non-induced cells were invasive. These observations suggested that upregulation of the AE2 protein in SW-48 cells indeed promotes their invasive behaviour. Consistent with this view, we also found that the opposite, i.e., AE2 overexpression in COS-7 cells renders the cell invasive, albeit the foci were small and consisted of only a few cells in each case 6D, E).

Another characteristic feature of cancer cells is their ability to grow and proliferate without attachment to the substratum. Therefore, we employed a colony formation assay in soft agar to test whether AE2 upregulation also contributes to this phenotype. Unlike SW-48 WT cells or non-induced and induced SW-48 Scr control cells, AE2 knockdown cells were able to form colonies only in the absence of doxycycline, but not in its presence (Fig. 6F, G). AE2 knockdown cells were present at low numbers and displayed fragmented nuclei (Fig. 6G insert), suggesting that they represent apoptotic cells. This may reflect the loss of anoikis resistance in AE2 knockdown cells, a special survival program that allows wild-type SW-48 cells to proliferate without any surface contact. Collectively, these findings suggest that upregulation of the AE2 protein in cancer cells has an important role in promoting SW-48 cell malignant phenotype.

\section{AE2 knockdown attenuates the expression of cancer-associated glycotopes in SW-48 cells}

To uncover why AE2 knockdown in SW-48 cells was able to reverse their invasive and anchorage-independent growth phenotype, we focused on the identification of potential glycosylation changes that differ between noninvasive cells (AE2 KD, COS-7) from the invasive ones (SW-48, SW-48 Scr). The rationale behind this is that cancer-associated glycosylation changes are well known to promote cancer cell invasiveness and metastatic spread [10-12, 45-47]. Moreover, Golgi glycosylation potential is highly dependent on its resting $\mathrm{pH}$ as shown above and earlier [13-15, 17, 18]. To accomplish this, we first compared the overall glycosylation patterns (Fig. S6) of the above four cell lines with each other. Heat map analysis (Fig. 7A) revealed that despite cell-type differences, 

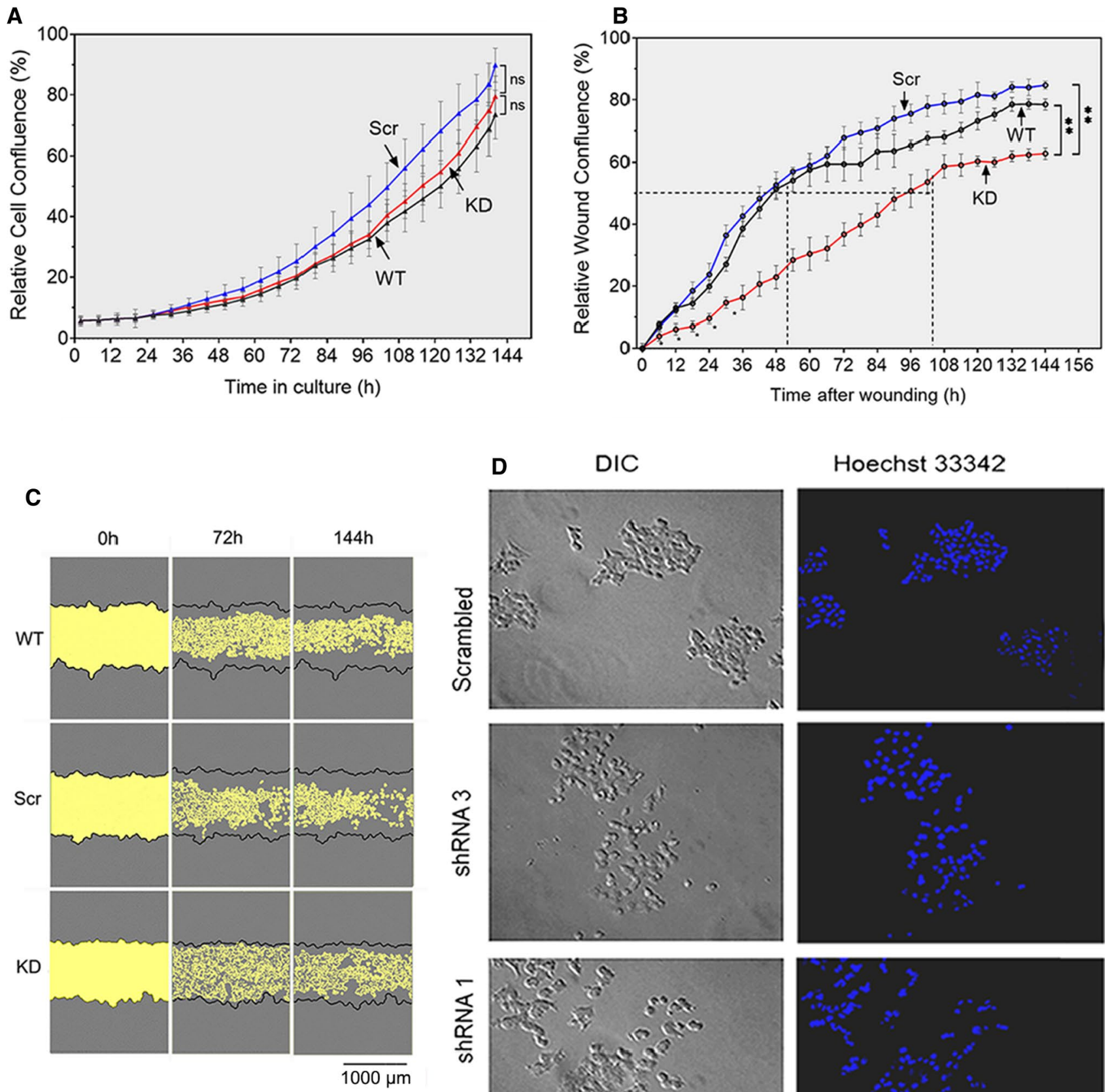

\section{D}
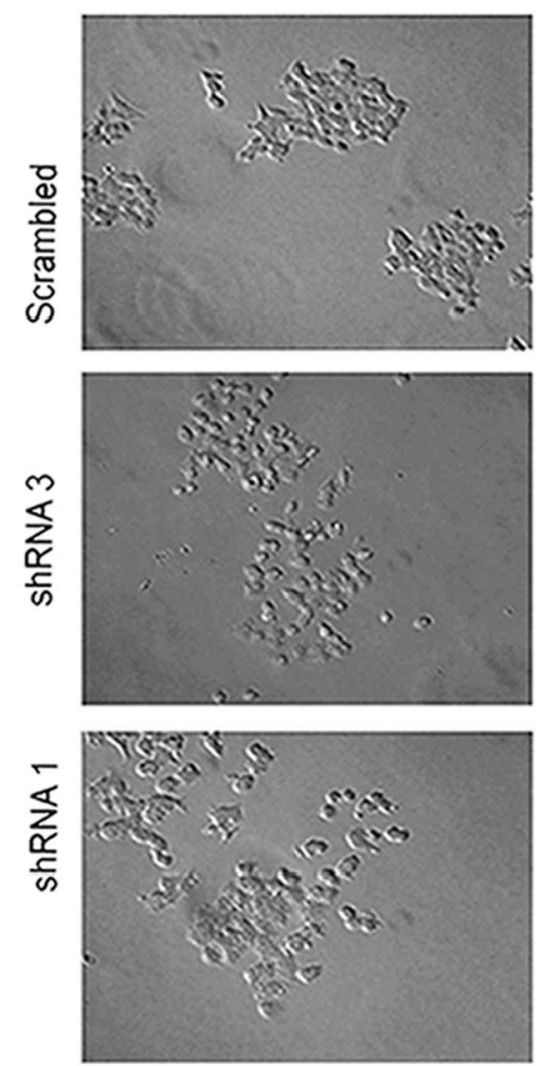

Hoechst 33342
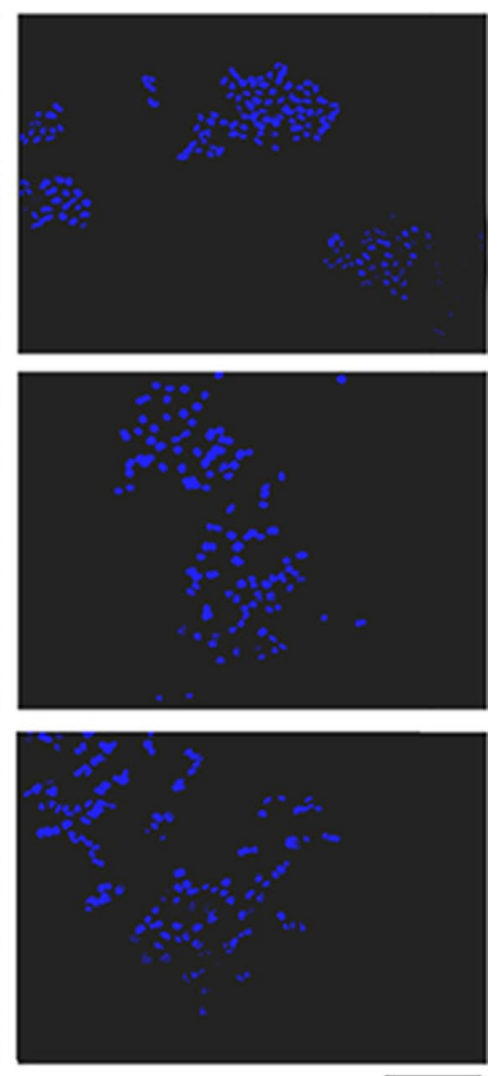

$\overline{100 \mu \mathrm{m}}$

Fig. 5 AE2 knockdown modulates SW-48 cell mobility and growth phenotype without affecting proliferation. A Cell proliferation rate measurements in AE2 knockdown cells in comparison to wild-type SW-48 cells and knockout controls (SW-48 Scr). IncuCyte ${ }^{\circledR}$ imaging system was used for the experiment. The means $( \pm \mathrm{SD}, n=9)$ of each time point were calculated using the instrument's software package before plotting against time. Cells stably transfected with the shRNA\#3 plasmid were used for the experiment. B Cell motility rate measurements using the scratch wound-healing assay. Confluent wells were scratched with an automated pin system, after which wound healing rate was followed against time by measuring cell confluence in the wound area using the in-built software. Cell confluence at each time point is shown as percentages of the wound area. C Representative figures are shown for each cell type. Cell-free areas are pinpointed by yellow colour. D Growth phenotype of AE2 knockdown cells carrying either the shRNA\#1 or the shRNA\#3 construct in comparison to control cells (SW-48 Src). In brief, cells were induced for 3 days with doxycycline, then fixed and stained with Hoechst 33,342 DNA dye before imaging with the differential interference contrast (DIC) microscopy. Representative figures are shown for each cell type 


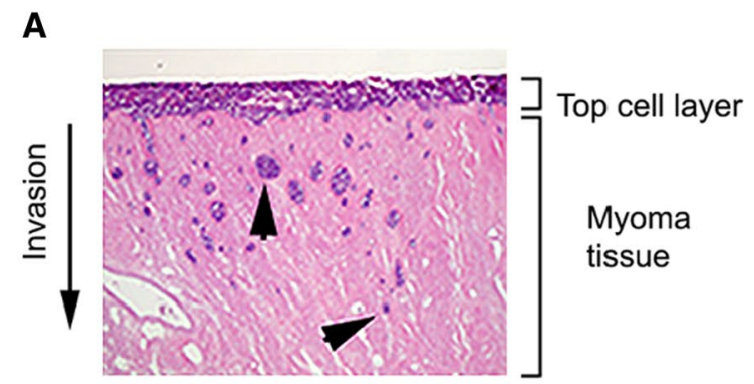

B

\section{SW-48 Scr}

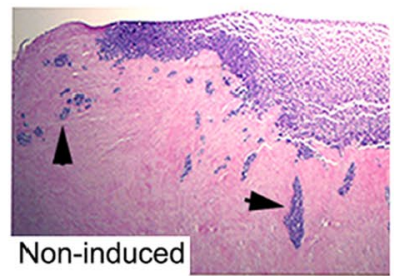

AE2 KD
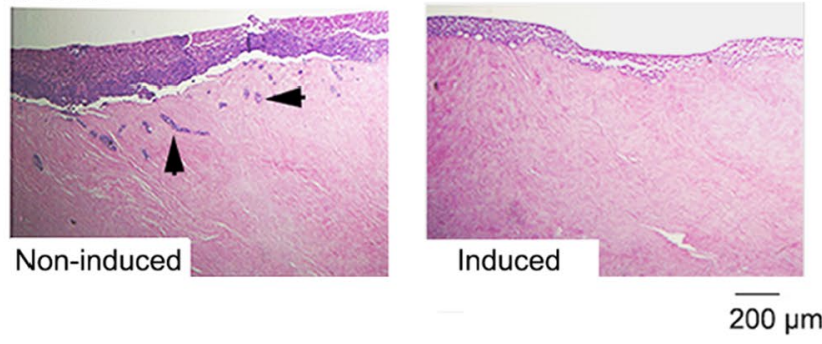

C

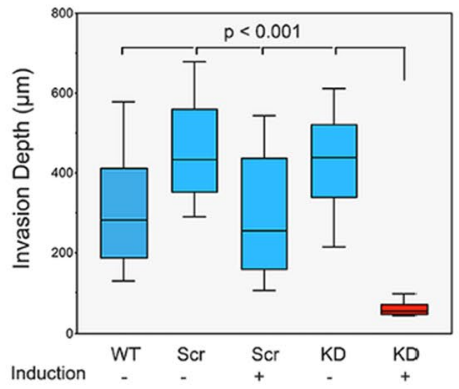

Fig. 6 AE2 knockdown in SW-48 cells reverses their invasive and anchorage-independent growth phenotype. A Myoma-tissuebased 3D invasion assay. Cells were seeded on top of myoma discs, allowed to grow for 21 days (with or without induction) before fixing and processing for immunocytochemistry. Sections were then cut perpendicularly to the seeded cell layer, stained, and imaged for quantification. Representative figures of invaded cells (invasive foci) inside the myoma tissue are shown (arrowheads). B Invasive potential of AE2 knockdown (KD) and control cells (SW-48Scr) were measured as above either with (Induced) or without (non-induced) doxycycline induction. Invasion depth was used as a measure of invasive potential. C A box plot presentation showing the median depth of the invasion foci from the top cell layer. Twelve sections from each myoma disc $(n=2 / 24)$ were used for the quantification with ImageJ software. The whiskers indicate 10th to 90th percentiles. D Invasive potential of wild-type COS-7 cells and AE2 overexpressing COS-7 cells (AE2plus). The invasion foci consisted mostly of single cells
D
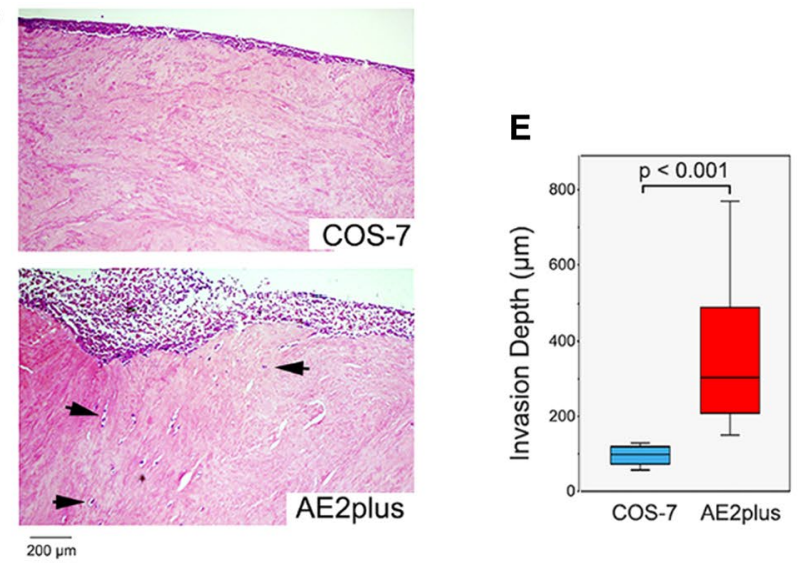

$\mathbf{F}$
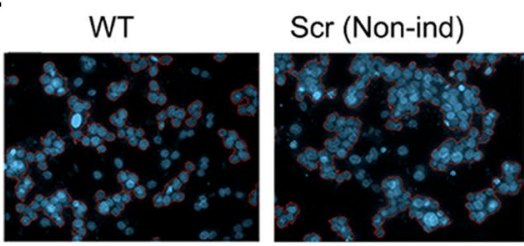

Scr (Induced)

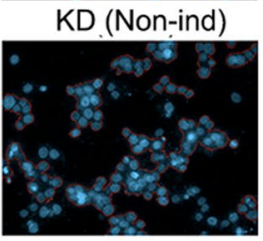

KD (Induced)
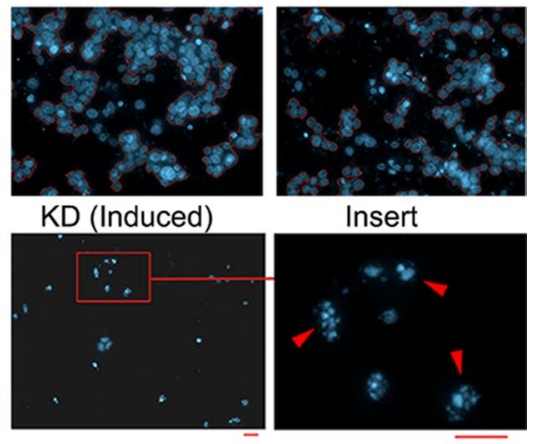

$20 \mu \mathrm{m}$

$20 \mu \mathrm{m}$

G

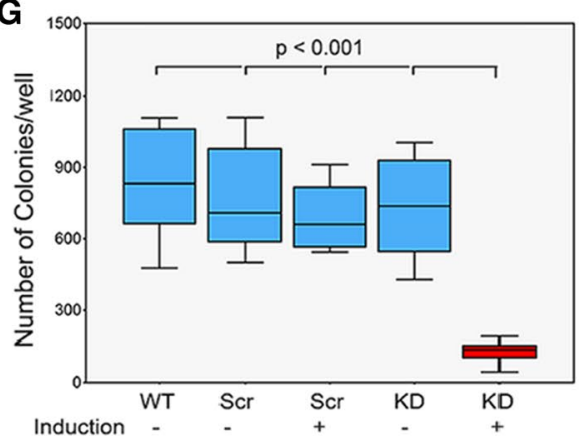

of which few are marked by arrows to pinpoint their existence. Note their absence in wild-type COS-7 cells. E A box plot presentation showing the median invasion depth of the foci in wild type and AE2 overexpressing COS-7 cells. The whiskers indicate 10th to 90th percentiles. F Colony formation assay in soft agar. Depicted cells (wild type SW-48cells (WT); AE knockdown cells (KD); SW-48 control cells (Scr) were grown in soft agar for 30 days with or without doxycycline induction (KD and Scr), after which cells were fixed and stained with Hoechst dye before imaging with the Operetta high content screening system. Representative figures are shown. The insert (bottom right) shows a higher magnification of the AE2 knockdown cells with fragmented nuclei (arrowheads). G The total number of colonies in each cell type. The number of cell colonies was quantified using the Harmony software. More than three nuclei in a pre-sized area were used to depict one colony. The results are shown as box plots with whiskers denoting 10th and 90th percentiles 
A

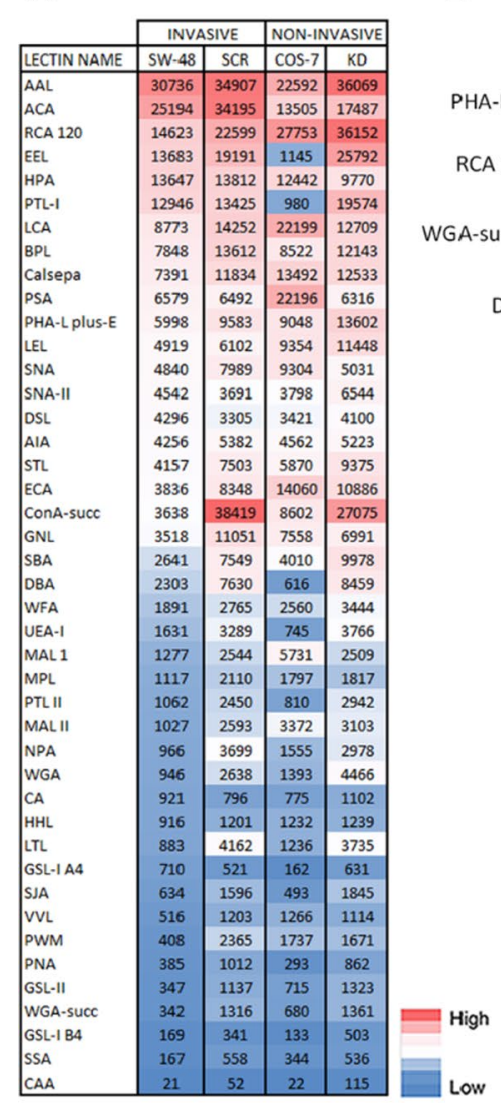

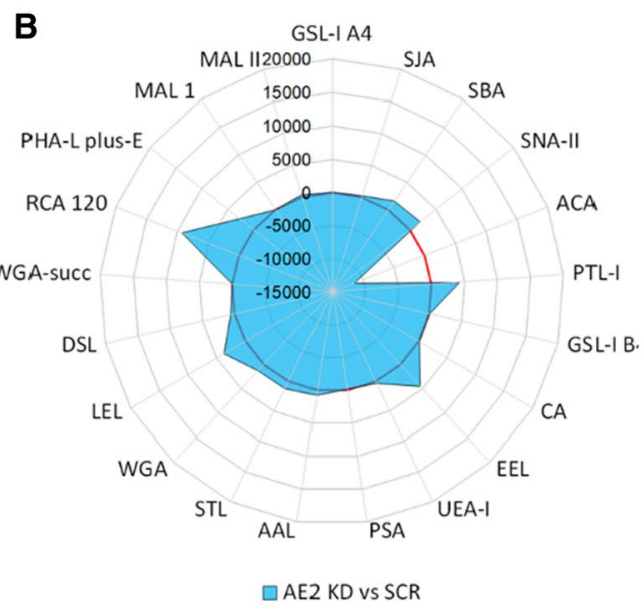

D

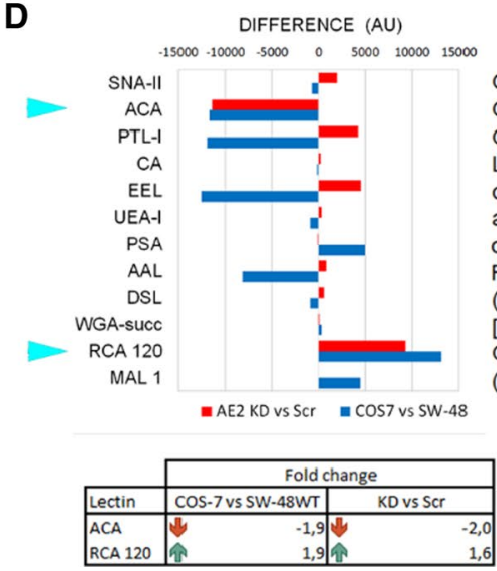

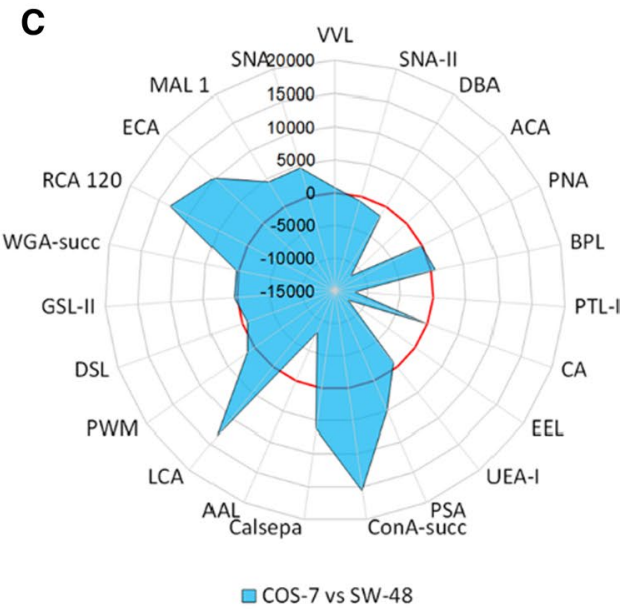

GalNAC $=\mathrm{Lac}>\mathrm{Gal}$

GalNAc, Gal $\beta(1,3)$ GalNAc

Gal, $\alpha$-GalNAc

Lac $>$ GalNAc > Gal

$\alpha-\operatorname{Gal}(1->3)(\alpha-F u c(1->2)-\beta G a l(1->3) / 4)-\beta-G I c N A c$

a-Fuc

a-Man, a-Gic

Fuca $(1,6)$ GlcNAc (core Fuc)

$(\mathrm{GlcNac} \beta 4) \mathrm{n}$, tri- and tetraantennary $\mathrm{N}$-glycans

$[\operatorname{GICNAC} \beta(1,4)] 3>[\operatorname{GICNAC} \beta(1,4)] 2>\operatorname{GICNAC}>>\mathrm{Neu} 5 \mathrm{AC}$

Gal $\beta(1-4)$ GIcNAc-R

(Siaa $(2,3))$ Gal $\beta(1,4)$ GlcNAC difference). C A radar plot showing statistically significant $(p<0.05)$ glycan-binding differences between COS-7 cells and SW-48 wild type (WT) cells. D Total lectin binding differences (subtracted fingerprints) between non-invasive and invasive cell pairs (AE2 knockdown cells vs. SW-48 Scr and SW-48 WT vs. COS-7). Only statistically significant differences that were common to both cell pairs are shown together with the lectin names and their corresponding glycotopes. Please notice that the overall glycosylation profiles (Fig. S6A, B) of each cell pair are comparable with each other with respect to the most and least abundant glycotopes, justifying their comparison their glycosylation patterns were rather similar, as the most and least abundant glycotopes were detected often with the same lectins. To identify the main differences between non-invasive and invasive cells, we compared AE2 knockdown cells with SW-48 Scr cells (KD vs. Scr) and COS-7 cells with SW-48 wild-type cells (COS-7 vs. SW-48 WT) despite their species difference. The use of SV40-transformed COS-7 cells in the latter cell pair is justified as glycans are highly similar between all mammalian cells $[48,49]$. They also continuously proliferate and became invasive upon AE2 overexpression. Comparison of subtracted fingerprint between KD and Scr cells (Fig. 7B) revealed 21 lectins that displayed significantly altered binding of their specific glycotopes. A similar comparison of non-invasive COS-7 cells with invasive SW-48 WT cells revealed significant changes in 23 out of 43 lectins (Fig. 7C). Further comparison of the two cell pairs with each other revealed 12 lectins that were common to both cell pairs (Fig. 7D). Interestingly, of these 12 lectins, only two lectins (ACA and RCA 120) showed comparable changes in both cell pairs. ACA lectin, which is specific for the truncated O-linked Tn- and T-antigens, showed significantly lower ( twofold) binding in noninvasive cells than in invasive cells. In contrast, RCA 120 lectin that is specific for galactose-containing complex type $\mathrm{N}$-glycans displayed significantly (1.9-1.6-fold) higher binding in non-invasive cells than in invasive cells. Thus, high expression of the truncated O-glycans and low 
level of terminally galactosylated $\mathrm{N}$-glycans appear to be closely associated with SW-48 cell invasiveness and anchorage-independent growth phenotype.

\section{Discussion}

In this report, we identified the long-sought" proton leakage" pathway that relies on AE2a-mediated bicarbonate-chloride exchange across Golgi membranes. Specifically, we showed that this pathway is strictly dependent on bicarbonate (and $\mathrm{Cl}^{-}$) anions as well as the level of the AE2a protein in the Golgi membranes. Therefore, because cytoplasmic bicarbonate and protons are present in the cytoplasm and dictate its resting $\mathrm{pH}$, Golgi resting $\mathrm{pH}$ also depends on cytoplasmic $\mathrm{pH}$. Electrochemical calculations also indicated that AE2a-mediated $\mathrm{HCO}_{3}{ }^{-} / \mathrm{Cl}^{-}$exchange is electrochemically favourable and sustained by both proton pumping and chloride channel-mediated $\mathrm{Cl}^{-}$influx down to its concentration gradient. Based on these observations, we presented a model in which proton leak across Golgi membranes involves net acid efflux via the well-known bicarbonate buffering reaction that produces water and carbon dioxide from luminal protons and bicarbonate anions. The reaction $\left(\mathrm{H}^{+}+\mathrm{HCO}_{3}{ }^{-}<>\mathrm{H}_{2} \mathrm{CO}_{3}<>\mathrm{CO} 2+\mathrm{H}_{2} \mathrm{O}\right)$ is reversible and proceeds spontaneously in the acidic Golgi lumen (see the supplementary video $\mathrm{S} 1$ ) while the opposite reaction (the production of $\mathrm{H}^{+}$and $\mathrm{HCO}_{3}^{-}$) takes place in the cytoplasm and is catalysed by CAII or by other members of this same family. The reaction is utilized universally among living organisms to regulate cytoplasmic and extracellular $\mathrm{pH}$ as well as the pH of body fluids [29, 30, 35, 42].

To be physiologically relevant, the two end products must be rapidly expelled across Golgi membranes. We envisage that this occurs either via direct diffusion or aquaporin channels because the latter can transport, besides water molecules, also other small molecules including glycerol, urea, nutrients, metabolic precursors, waste products, toxins, and even gases such as $\mathrm{CO}_{2}$ [40, 41]. In this context, it is interesting, and perhaps not even unexpected, to note that the flattened morphology of the Golgi cisternae can accelerate this process as their shape provides an optimal surface-volume ratio for gas and water exchange. The need to prevent water and carbon dioxide from accumulating in the Golgi lumen while keeping Golgi buffering capacity in balance may be one of the main reasons for their unique morphology in mammalian cells. In addition, it is probably not a mere incidence that the $\mathrm{pKa}$ of the bicarbonate buffering system is within the same range as the Golgi resting $\mathrm{pH}$ in mammalian cells (pKa 6.4 vs. pH 6.7-6.0).

The membrane topology of the AE2 anion exchanger and its $\mathrm{pH}$-dependent anion exchange activity is also consistent with the model. Both the $\mathrm{N}$-and C-termini of the Golgi- and plasma membrane-localized AE2 protein face the cytoplasm and enable various protein interactions that appear to regulate anion exchange activity or the compartmental localization of the protein in the cells $[28,30,32,36]$. All AE2 isoforms also function against alkaline loads, whereby they export bicarbonate anions (a weak base) to the extracellular space (in exchange for $\mathrm{Cl}^{-}$anions) or the Golgi lumen, given their identical membrane topology. Previously, it has been also shown that the AE2 anion exchange activity is pH-dependent, i.e., it is active above $\mathrm{pH} 5.0$ [50]. Therefore, it retains its activity in the Golgi, where the resting $\mathrm{pH}$ is above $\mathrm{pH}$ 6.0. Yet, the $\mathrm{pH}$ sensitivity of the AE2 protein may act as a safeguard mechanism to prevent other more acidic organelles compartments (such as secretory vesicles or lysosomes) from alkalinizing in a case AE2 might get mislocalized there. Considering this, and the predominant localization of the AE2a variant in the Golgi membranes in a variety of cells, suggests that the AE2-mediated net acid efflux pathway applies only to the Golgi compartment and perhaps also to the endoplasmic reticulum (ER), given that both AE1 and AE2 acquire their anion exchange already in the ER [51].

The functional relevance of the AE2-mediated net acid efflux pathway was verified by showing that both the AE2 mRNA and protein levels are often upregulated in cancers and established cancer cell lines. In SW-48 cells, this could result from the amplification of chromosome 7 $(47+\mathrm{XX},+7)$, the chromosome in which the AE2 gene locates in humans [52]. Alternatively, it could be due to epigenetic changes or environmental factors such as hypoxia $[13,53]$. Nevertheless, upregulation of the AE2 protein was found to have important consequences on cancer cell phenotype most likely via its ability to modulate Golgi resting $\mathrm{pH}$. We showed that a high AE2 protein level in SW-48 cells was associated with near-neutral Golgi resting $\mathrm{pH}$ and that AE2 knockdown restored it to near-normal levels. Moreover, keeping in mind that $\mathrm{AE} 2$ protein expression level correlated well with the Golgi resting pH in COS-7 cells (Fig. 1), AE2 overexpression is very likely responsible for their elevated Golgi resting $\mathrm{pH}$. In this regard, it is important to notice that the AE2 protein was expressed also at the cell surface. Therefore, it is possible that AE2 knockdown increases bicarbonate levels (and $\mathrm{pH}$ ) in the cytoplasm via attenuating their export to the extracellular space, in line with the known functions of the AE2 proteins against alkaline loads. This is in line with our notion that the cytoplasmic $\mathrm{pH}$ was slightly elevated in AE2 knockdown cells when compared to control cells. Such an increase, however, did not affect cell proliferation rate but may contribute to Golgi resting pH by counteracting AE2 knockdown-mediated loss of the protein in the Golgi and thus explain why the Golgi resting $\mathrm{pH}$ in AE2 knockdown cells plateaued at $\mathrm{pH} \sim 6.5$, i.e., 0.2 $\mathrm{pH}$ units above the mean Golgi pH in COS-7 cells. 
Recently, Galenkamp et al. [27] introduced a new hypothesis that suggests that the Golgi acts as a proton sink or reservoir in cancer cells. It is well known that cytoplasmic $\mathrm{pH}$ is more alkaline in cancer cells than in normal cells and necessary for their proliferation and growth [1-3, 27]. An altered energy metabolism (glycolysis) is needed also for continuous proliferation, however, counteracts this need, as it increases acid load in the cells. Cancer cells can normally cope with this extra acid load by launching several independent proton removal pathways, one of which involves proton import to Golgi lumen via ATP-mediated proton pumping or the sodium-hydrogen exchanger NHE7. Therefore, an increased Golgi buffering capacity in the Golgi (due to AE2 overexpression) seems to be beneficial to cancer cells, as it allows more protons to be neutralized through this pathway. The other side of the coin is that the Golgi resting $\mathrm{pH}$ becomes too alkaline for its main tasks including membrane trafficking and glycosylation [13-18]. Such a high buffering capacity in the Golgi may also explain why it has been difficult to demonstrate that the NHE7 functions as an acid loader in the Golgi [25, 26]. However, how other cancer cell types that do not overexpress the AE2 protein, can cope with extra acid load remain unclear but they likely use alternative pathways for expelling protons from the cell for example through the plasma membrane or via endocytic compartments [27]. Another issue that needs to be clarified is why some cancer cell types display elevated Golgi resting $\mathrm{pH}$ without AE2 overexpression. We anticipate that in these cells elevated Golgi resting $\mathrm{pH}$ likely reflects the altered activity of any of the other transporters or enzymes that contribute to Golgi resting $\mathrm{pH}$. Potential candidate proteins include the V-ATPase, GPHR, GOLAC, CAII, and CAIV. In support of this possibility, our immunoblotting data on CAII showed that this bicarbonate and the proton-producing enzyme are upregulated in MCF-7 cells.

The finding that AE2 knockdown was able to reverse SW-48 cells non-invasive and unable to grow in soft agar without affecting their proliferation markedly is intriguing, as it indicates that AE2 overexpression can promote cancer cell invasiveness and anchorage-independent growth, i.e., two phenomena that are typical for malignant cells. Thus, an important issue is how elevated Golgi resting $\mathrm{pH}$ can alter cancer cell malignant behaviour to mimic that of a benign cell. Clarifying this may be challenging due to the multi-faceted nature and the vast number of pathways that contribute to the malignant behaviour of cancer cells. Yet, altered glycosylation may be a unifying factor as it can affect multiple pathways at the same time. Consistent with this, the activity of cell adhesion receptors, receptor tyrosine kinases, death receptors, and matrix metalloproteinases is regulated by their glycosylation status [54-57]. For example, integrins that consist of variable $\alpha$ and $\beta$ heterodimers, contain multiple potential $\mathrm{N}$-linked glycosylation sites on each subunit.
The $\beta 1$ subunits, which are best characterized, normally carry $N$-acetyllactosamine $(\mathrm{Gal} \beta(1,4) \mathrm{GlcNAc})$ type multiantennary structures [54]. Their capping with either $\alpha(2,3)$ or $\alpha(2,6)$-linked sialic acid and $\beta(1,6)$-GlcNac branching was also shown to have profound effects on cell adhesion and motility [56]. In this respect, it is interesting to note that we detected marked differences in the level of this same glycotope between non-invasive (AE2 KD, COS-7) and invasive (SW-48 WT, SW-48 Scr) cells, the former displaying significantly higher levels of this glycotope. Another example of the role of glycans in promoting cancer cell malignant behaviour is the matrix metalloproteinase MMP14, the main enzyme needed for cancer cell invasiveness. Bard and his group [55] recently showed that O-glycosylation of MMP14 by the initial GalNAc residue is markedly enhanced due to relocalization of relevant GALNT glycosyltransferase to the ER. In a mouse liver cancer model, this increase in turn markedly increased MMP14 activity as well as tumour cell invasion and tumour expansion. In addition, impaired O-glycosylation and in particular, the extension of the (sialyl)Tnantigen to (sialyl)-T-antigen of the TRAIL death receptor was found to alter receptor oligomerization state and to confer apoptosis resistance to the cells [54]. Overexpression of C1GALT1, a key enzyme controlling the elongation of the Tn-antigen to T-antigen in turn was also found to enhance migration, invasion, tumour growth, and metastasis of pancreatic cancer cells [58]. In line with these observations, our lectin microarray analyses showed that the levels of these truncated O-glycan glycotopes were much lower in non-invasive AE2 knockdown cells than in invasive (SW$48 \mathrm{Scr}$ ) cells. Taken together, these findings suggest that high expression of the truncated O-glycan glycotopes and low level of terminally galactosylated $\mathrm{N}$-glycans represent potential candidates that may promote cancer cell malignant phenotype. Yet, more detailed glycan analyses, even at the protein- and glycosylation site-specific level [55], are needed to prove or disproof their exact contribution to cancer cell malignant phenotype.

In summary, we showed that overexpression of the AE2 protein in cancer cells promotes their malignant behaviour via enhancing net acid efflux across Golgi membranes (Fig. 8). Thereby, the Golgi resting $\mathrm{pH}$ becomes more alkaline which in turn impairs normal processing and maturation of both $\mathrm{N}$ - and O-glycan. Altered glycans then promote cancer cell invasiveness and anchorage-independent growth phenotype. We were also able to reverse these phenomena by knocking down the AE2 protein with AE2-specific shRNAs, whereby malignant SW-48 cells lost their invasive and anchorageindependent growth phenotype, i.e. properties typical for benign cells. In support of these data, earlier studies data have shown that the activity of various proteins that regulate cell adhesion, cell motility, invasion, and metastasis is dependent on their glycosylation status. Yet, the exact roles of altered 


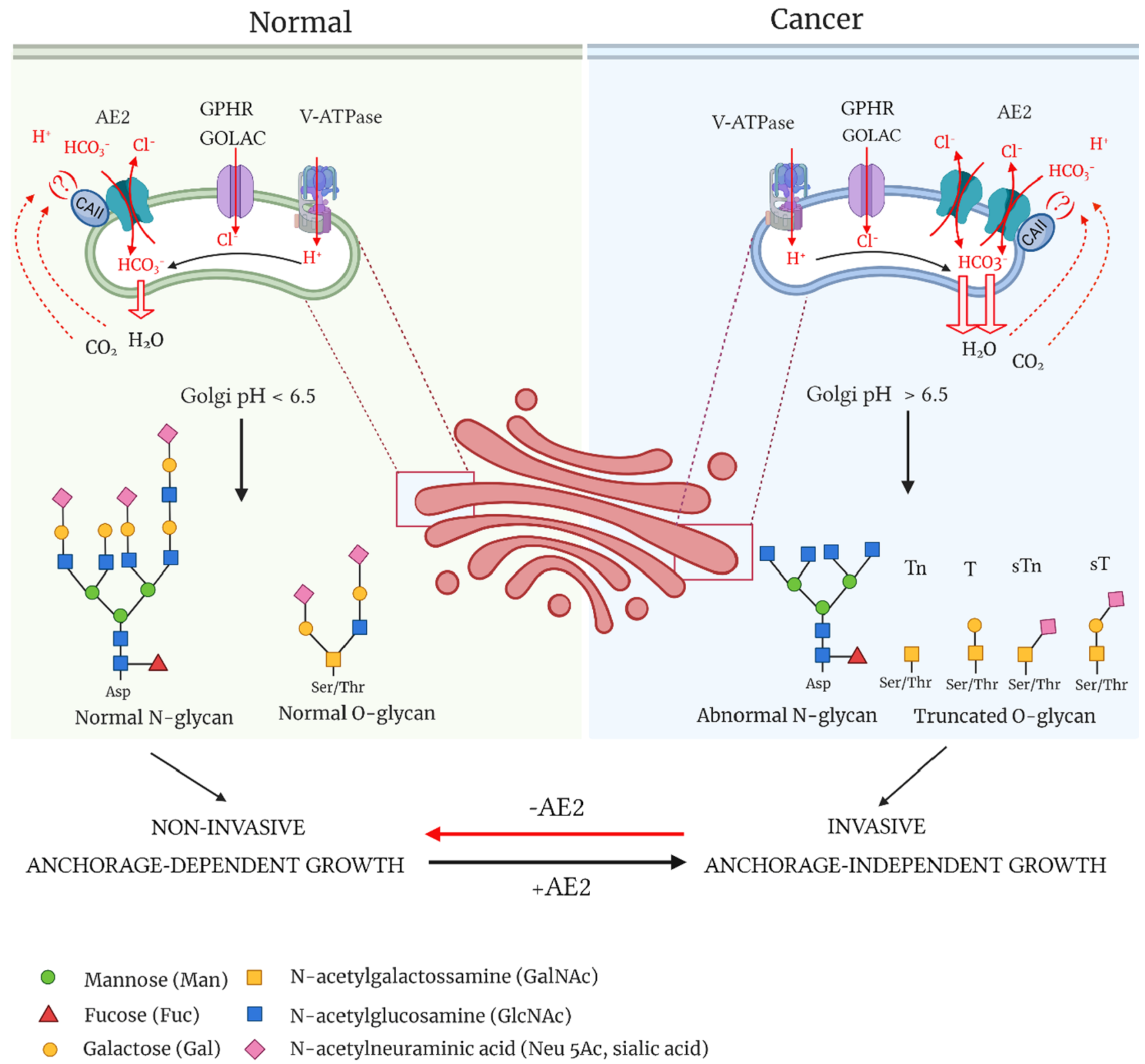

Fig. 8 A summary cartoon of the AE2-mediated net acid efflux pathway and its consequences on cancer cell behavior. For more details see the main text

glycans in promoting cancer cell invasiveness and anchorageindependent growth, remain to be clarified. It is also important to emphasize that altered glycans seem to promote these phenomena only in cells that are committed to continuously proliferate and grow (such as SW-48 and SV40-transformed COS-7 cells) since patients with autosomal recessive cutis laxa type 2A (ARCL2A) do not show enhanced cancer risk despite they carry an inactive V-ATPase and display abnormal glycans $[59,60]$. Therefore, our findings do not neglect the importance of genetic mutations as the main drivers of tumorigenesis. Rather, they suggest that the main role of altered glycans is to promote tumour progression, i.e., when a benign cell turns into a malignant cell. Thus, our findings may open new possibilities in the future to prevent the metastatic spread of cancers, the main cause of death of cancer patients. In the worst case, they could be exploited to develop new diagnostic tools for detecting metastasis-prone tumours and thereby improve patient care. 


\section{Materials and methods}

\section{Reagents, antibodies, and plasmids}

All reagents were purchased from Sigma-Aldrich (St. Louis, MO, USA) unless stated otherwise. The antibodies against the Golgi marker GM130 were purchased from BD Biosciences (\#610,822, San Jose, CA, USA). The horseradish peroxidase-conjugated secondary antibodies were from Appliance (Compiègne, France). An antibody against AE2 C-terminal peptide was prepared and affinity-purified as described earlier [61]. Alexa Fluor488- and 594-conjugated anti-mouse and anti-rabbit secondary antibodies and AlexaFluor488- or Alexa594-conjugated peanut agglutinin (PNA) were purchased from Molecular Probes (Eugene, OR, USA) or Invitrogen (Carlsbad, CA, USA). Unconjugated lectins were purchased from either EY laboratories (San Mateo, CA, USA) or Vector Laboratories Inc. (Burlingame, CA, USA). Anti- $\alpha$-tubulin antibody was from Sigma Aldrich (St. Louis, MO, USA). The plasmid encoding the medial/transGolgi localized pHluorin [33] was a kind gift from Dr. G. Miesenböck (Oxford, UK). The AE2-mCherry plasmid was prepared by sub-cloning the full-length AE2 in-frame into the pcDNA3-monomeric Cherry (mCherry) vector (Invitrogen, Carlsbad, CA, USA).

\section{Cell culture and transfections}

All cell lines (COS-7, HeLa, HT-29, SW-48, CaCo-2, DLD1, MCF-7, MDA-MB 231, RCC4, A431) were from ATCC (Manassas, VA). Cells were grown in high glucose Dulbecco's modified Eagle's medium (DMEM) supplemented with Glutamax (Gibco BRL, Grand Island, NY, USA), 10\% fetal bovine serum (HyClone, Cramlington, UK), and antibiotics (100 U/ml Penicillin and $100 \mu \mathrm{g} / \mathrm{ml}$ Streptomycin; SigmaAldrich, St. Louis, MO) in humidified conditions at $+37^{\circ} \mathrm{C}$ and $5 \% \mathrm{CO}_{2}$. Transfections were performed using either the Lipofectamine ${ }^{\circledR} 3000$ (Thermo fisher scientific, CA, USA) or the FuGENE $6^{\mathrm{TM}}$ (Promega, Fitchburg, WI, USA) transfection reagents according to the suppliers' instructions for 1-2 days before the experiments. In certain cases, cells were also transfected with electroporation using Amaxa ${ }^{\mathrm{TM}}$ Nucleofector Kit R (Cat.no.VCA-100) and the Nucleofector ${ }^{\mathrm{TM}} \mathrm{II}$ device (program W-001, Lonza Group AG, Cologne, Germany) as suggested by the manufacturer.

\section{Immunofluorescence electron microscopy}

Immunofluorescence microscopy was performed by fixing cells with $2 \%$ p-formaldehyde ( $30 \mathrm{~min}$ ), after which cells were permeabilized with $0.1 \%$ saponin in PBS and stained with the anti-GM130 antibody or with AlexaFluor488- or Alexa594-conjugated lectins (1 h at RT). After washing, cells were treated with relevant species-specific Alexa Fluor488- and 594-conjugated anti-mouse or anti-rabbit secondary antibodies. After mounting, cells were imaged using Olympus BX 51 microscope with appropriate filter sets for the dyes. Alternatively, Zeiss Observer Z1 confocal microscope (LSM 700, Carl Zeiss AG, Oberkochen, Germany) with appropriate filter sets, the Zen2009 software, a 63X Plan-Apo oil-immersion objective, was used. Colocalization studies of the mCherry fusion constructs or GT-pHluorin constructs with the Golgi marker (GM130) antibody were done using Alexa488 or Alexa 594-conjugated secondary antibodies, respectively.

\section{Immunoblotting}

Immunoblotting of the $\alpha$-tubulin (used as a loading control) was carried out by using sodium dodecyl sulfate-polyacrylamide gel electrophoresis (SDS-PAGE). In brief, cells were lysed on plates with the lysis buffer $(50 \mathrm{mM}$ Tris- $\mathrm{HCl}$ (pH 7.5), $150 \mathrm{mM} \mathrm{NaCl} ; 1 \%$ TX-100; 2 mM EDTA; 2 mM EGTA) supplemented with protease inhibitors (Complete Mini, Roche, Basel, Switzerland). After clearing $(15,000 \mathrm{~g}$ for $15 \mathrm{~min}$ ), $50-100 \mu \mathrm{g}$ of total protein in SDS-sample buffer was separated using 7.5\% SDS-PAGE gels.

Blue-native polyacrylamide gel electrophoresis was used for immunoblotting of the AE2a protein as described below. Cells were washed twice with PBS, scraped from the dishes, pelleted by centrifugation, and lysed on ice in TND/TX-100 buffer (25 mM Tris pH 7.5, $150 \mathrm{mM} \mathrm{NaCl}, 0.5 \%$ Deoxycholic acid, 1\% Triton X-100) for $1 \mathrm{~h}$. After clearing by centrifugation $(15,000 g,+4 \mathrm{C}, 15 \mathrm{~min})$, the TX-100 soluble fractions were mixed with $5 \times$ Tris/Glycerol native sample buffer before loading onto a 4-15\% Mini-Protean TGX gel (Bio-Rad, Hercules, CA). The samples were run in Tris/ Glycine buffer supplemented with 0.02\% Coomassie Brilliant BlueG-250 until the samples had migrated $1-2 \mathrm{~cm}$ into the gel, and thereafter without the dye at $20 \mathrm{~mA}$ for $2 \mathrm{~h}$. The samples were transferred onto the PVDF membrane (BioRad) with Bio-Rad Trans-blot Turbo for a mixed molecular weight program (1.3A-25 V; $7 \mathrm{~min})$. The membrane was quenched by using $5 \%$ non-fat milk in TBS-Tween $(50 \mathrm{mM}$ Tris- $150 \mathrm{mM} \mathrm{NaCl}-0.02 \%$ Tween $20, \mathrm{pH} 7.6$ ) supplemented with $0.1 \%$ BSA overnight at $+4 \mathrm{C}$. The blot was then incubated with a polyclonal anti-AE2 C-terminal antibody (anti-AE2Ct) or the mouse monoclonal anti $\alpha$-tubulin antibody (Sigma Aldrich, St. Louis, MO, USA) in TBS-Tween $20+0.1 \% \mathrm{BSA}$ ) for $2 \mathrm{~h}$ at RT. After washing 3 times for 10 min with TBS-Tween 20, rabbit anti-mouse or goat antirabbit HRP-conjugated secondary antibodies (Abliance, Compiègne, France) were added in TBS-Tween-0.1\% BSA for $1 \mathrm{~h}$ at RT (1:10.000 dilution). After final washings (4 
times $15 \mathrm{~min}$ in TBS-Tween), protein bands were visualized using the ECL reagent and the GelDoc instrument (both from Bio-Rad, Hercules, USA) before quantification using the build-in Image Lab software.

\section{Knockdown of AE2a in COS-7 and SW-48 cells}

Given the lack of hereditary human diseases related to human AE2, and the severe phenotype described for SLC4A2 (AE2) knockout mice [27], we decided to utilize an inducible shRNA-mediated gene silencing of the AE2a protein (as well as other AE2 transcripts) that also allowed us to control AE2 expression level in the cells. Cells were transfected with the AE2-specific and control (scrambled) shRNAs using the inducible SMART-vector constructs (Dharmacon, Lafayette, CO, USA) as suggested by the manufacturer. The shRNA sequences are shown in Table S1. Stably transfected cells were selected first against puromycin (Gibco, 0.75-1.5 $\mu \mathrm{g} / \mathrm{ml}, 48 \mathrm{~h}$ ) before repeated sorting of cells by fluorescent activated cell sorter (BD FAC$\mathrm{SAria}^{\mathrm{TM}}$ ) and collecting cells with high ( $>$ tenfold over the background) doxycycline-inducible RFP expression. Cell lysates were then prepared from the stable transfectants with or without doxycycline induction (50-250 ng/ml) for $72 \mathrm{~h}$ and used for the determination of the AE2a protein expression levels by immunoblotting of the cell lysates with the AE2 C-terminal antibody as described above.

\section{Lectin microarray analyses}

Cells cultivated on plates to $70-80 \%$ confluency were lysed for $30 \mathrm{~min}$ on ice with lysis buffer $(50 \mathrm{mM}$ sodium tetraborate buffer, $\mathrm{pH} 8.5,150 \mathrm{mM} \mathrm{NaCl}, 1 \%$ Triton $\mathrm{X}-100)$ supplemented with the protease inhibitor cocktail (Complete Mini, Roche) and clarified by centrifugation $(12,000 \times g$ at $4{ }^{\circ} \mathrm{C}$ for $15 \mathrm{~min}$ ). $12 \mu \mathrm{g}$ of total protein of each cell lysate was labelled with $6 \mu \mathrm{g}$ of NHS activated DyLight 630 dye (Thermo Scientific, Waltham, USA) in $50 \mu \mathrm{l}$ of labelling buffer ( $50 \mathrm{mM}$ boric acid/150 mM NaCl, $\mathrm{pH} 8.5$ ) for $1 \mathrm{~h}$ at RT with constant agitation $(600 \mathrm{rpm})$. The reaction was quenched at RT for $1 \mathrm{~h}$ by adding $50 \mu \mathrm{l}$ of quenching buffer (75 mM ethanolamine in $200 \mathrm{mM}$ Tris- $\mathrm{HCl} / 150 \mathrm{mM} \mathrm{NaCl}$, $\mathrm{pH}$ 8.5) before dilution (1:12) with the assay buffer $(50 \mathrm{mM}$ Tris/300 mM NaCl/2 mM MgCl$/ 2 \mathrm{mM} \mathrm{MnCl}_{2} / 2 \mathrm{mM}$ $\mathrm{CaCl}_{2}, \mathrm{pH}$ 7.1) to give the final $\mathrm{pH} 7.4$ to the labelled sample mix. After clearing the mix by centrifugation $(12,000 \times \mathrm{g}$ for $10 \mathrm{~min}$ at RT), $400 \mu \mathrm{l}$ of the labeled sample was applied to each well on pre-printed and pre-quenched (with $50 \mathrm{mM}$ ethanolamine) Nexterion H microarray slides (Schott, Germany). The labeling was further incubated in a humidified chamber with constant agitation for $2 \mathrm{~h}$ in RT. Slides were then washed five times for 5 min each with the washing buffer (50 mM phosphate buffer/0.05\% Tween). Array images were generated using the Genepix 4200AL laser scanner (Axon Instruments) using an appropriate filter set for the DyLight $633^{\mathrm{TM}}$ dye. The mean intensities of bound labels were quantified in triplicate from four parallel arrays (36 measurement spots/sample) using the GenePix Pro ${ }^{\circledR}$ microarray analysis software. Sugar binding specificities of the lectins were deduced from the manufacturer's product sheets. The corresponding lectin names are available upon request. The specificity of the lectins for their glycotopes was verified during the optimization of the protocol by using labelled fetuin and asialofetuin as markers.

\section{Organelle resting $\mathrm{pH}$ measurements}

Golgi resting $\mathrm{pH}$ in the cells was determined as follows. Briefly, after equilibration in the assay buffer (PBS supplemented with $0.5 \mathrm{mM} \mathrm{MgCl} 2,0.9 \mathrm{mM} \mathrm{CaCl}_{2}$, and $4.5 \mathrm{~g} / 1$ D-Glucose (PBS/D-Glucose) at RT without $\mathrm{CO}_{2}$, the Golgi region of the cells expressing the GT-pHluorin were imaged by using the Operetta ${ }^{\mathrm{TM}}$ high content imaging system (PerkinElmer Inc.). In situ $\mathrm{pH}$ calibration was done by replacing the bath solution with different $\mathrm{pH}$ calibration buffers $\left(125 \mathrm{mM} \mathrm{KCl}, 20 \mathrm{mM} \mathrm{NaCl}, 1.0 \mathrm{mM} \mathrm{CaCl}_{2}, 1.0 \mathrm{mM}\right.$ $\mathrm{MgCl}_{2}$ ) pre-adjusted to $\mathrm{pH} 7.5, \mathrm{pH} 6.5$, and $\mathrm{pH} 5.5$ with $20 \mathrm{mM}$ HEPES, MOPS, or MES, respectively. Ionophores ( $5 \mu \mathrm{M}$ nigericin, $5 \mu \mathrm{M}$ monensin) were included in the buffers to dissipate the existing monovalent $\left(\mathrm{H}^{+}, \mathrm{K}^{+}, \mathrm{Na}^{+}\right)$ ion gradients. Cytoplasmic $\mathrm{pH}$ was measured as above, except that the Golgi targeting signal was omitted from the pHluorin plasmid construct.

Golgi acidification and leakage rate measurements were performed in triplicate as described below. Cells expressing the pHluorin were equilibrated as above, imaged, and then permeabilized with Streptolysin O (SLO, $3 \mu \mathrm{g} / \mathrm{ml}$ ) either in chloride-free or chloride-containing high potassium buffer (120 mM KCl, $30 \mathrm{mM} \mathrm{NaCl}, 10 \mathrm{mM}$ EGTA, $10 \mathrm{mM} \mathrm{MgCl}_{2}, 10 \mathrm{mM}$ Hepes, $\mathrm{pH}$ 7.2). Chloride-free high potassium buffer contained corresponding gluconate/sulphate salts instead of chloride anions, which cannot be used for AE2a-mediated bicarbonate exchange [43]. Bicarbonate was added to the chloride-containing bath medium just before the assay was started. Golgi acidification rate (a sum of proton pumping and its leakage rates) was followed by adding fresh ATP $(10 \mathrm{mM})$ to the bath solution. Ratio imaging ( $15 \mathrm{~s}$ intervals) of the selected Golgi regions was performed until the ratios (Golgi $\mathrm{pH}$ ) reached a plateau. The Zeiss Axio Observer Z1 microscope equipped with a dual FRET camera system and appropriate filter sets for two different excitations (420 and $470 \mathrm{~nm}$ ) and one emission (500-550 nm) wavelengths were used for imaging. Net acid efflux rates were then measured by replacing the ATP-containing buffer with an ATP-free buffer with added concanamycin A (CMA, $1 \mu \mathrm{M})$, a potent V-ATPase 
inhibitor. Net acid efflux (i.e. Golgi pH increase) was then followed again by ratio imaging until it reached a plateau. At the end of each experiment in situ-pH calibration was performed by using pre-calibrated calibration buffers $(\mathrm{pH}$ $5.0,5.5,6.0,6.5,7.0$, and 7.5) as above. Intensity ratios were then transformed to $\mathrm{pH}$ values using the determined formulas for the obtained sigmoidal calibration curves. Numerical data were processed using Microsoft ${ }^{\circledR}$ Excel solver (Redmond, WA, USA).

\section{Immunoblotting of human colorectal cancer tissue samples}

All human cancer tissue specimens were obtained from the Pathology research unit, Oulu University Hospital following Institutional Ethical Committee Review Board guidelines (permission numbers. 25/2002, 42/2005, 122/2009). Fresh samples were frozen and stored at $-80{ }^{\circ} \mathrm{C}$ until use. Proteins were extracted using $500 \mu \mathrm{l}$ of ice-cold lysis buffer (50 mM Tris-HCl, pH 7.4, $150 \mathrm{mM} \mathrm{NaCl}, 1 \%$ Triton $\mathrm{X}-100,0.5 \%$ deoxycholic acid with a protease inhibitor) and pre-cooled tissue homogenizer (TissueLyser LT, Qiagen $\mathrm{GmbH}$, Hilden, Germany) for 2-4 min at $45 \mathrm{~Hz}$. After homogenization, the lysates were clarified by centrifugation $\left(15,000 \mathrm{rpm}, 15 \mathrm{~min}\right.$ at $\left.+4{ }^{\circ} \mathrm{C}\right)$ and run on Blue-native gel electrophoresis (for AE2) and SDS-PAGE (for $\alpha$-tubulin) as described in the main text.

\section{Cell proliferation and wound healing migration assays}

The assays were performed using the IncuCyte ${ }^{\circledR}$ Live-Cell Analysis System and established protocols (Essen BioScience, Newark Close, and UK). In brief, for cell proliferation assays, wild-type SW-48 cells and cells stably transfected with the scrambled or AE2-specific shRNAs plasmids were plated into special 96 -well plates $\left(5 \times 10^{3}\right.$ cells/well $)$ and cultured in DMEM supplemented with 10\% FCS and penicillin-streptomycin for 6 days. Cells were imaged at $2 \mathrm{~h}$ intervals during the 5-day culture period before quantification with the IncuCyte ${ }^{\circledR}$ software.

For the scratch wound cell migration assay, $5 \times 10^{4}$ cells/ well were plated and after reaching confluence, cell monolayers were grown on Image Lock 96-well microplates (Essen Bioscience) in DMEM with 1\% FCS after scratching 700-800 $\mu \mathrm{m}$ wide "wounds" using the 96 pin IncuCyte ${ }^{\circledR}$ Wound Maker (Essen Bioscience). Wound closure (migration) was then followed by using phase-contrast imaging for 6 days at $2 \mathrm{~h}$ intervals. Basic IncuCyte ${ }^{\circledR}$ software and settings were used for the analyses. The data are expressed as percentages of confluence in each well.

\section{D invasion assay}

The invasive properties of wild-type SW-48 and AE2 knockdown cells as well as COS-7 cells stably overexpressing the AE2a variant (G418 selection) were investigated using an established organotypic 3D-myoma-invasion model [44]. In brief, myoma discs pre-equilibrated at $+4{ }^{\circ} \mathrm{C}$ in DMEM were placed in tightly fitted Transwell ${ }^{\circledR}$ inserts (Corning, Inc., Corning, NY, USA) after which $5 \times 10^{5}$ cells (in $50 \mu \mathrm{l}$ of DMEM) were added on top of each disc. After attachment, myoma discs with cells were transferred onto uncoated nylon discs placed on curved steel grids $(3 \times 12 \times 15 \mathrm{~mm})$ in 12 -well plates, each well-containing $1 \mathrm{ml}$ of fresh media with and without doxycycline. The myoma organotypic cultures were maintained for 14 days with daily media changes. Each assay was performed in triplicate. The specimens were fixed in $4 \%$ formalin overnight, dehydrated, and embedded in paraffin. Finally, $6 \mu \mathrm{m}$ thick sections were cut and deparaffinized before staining with Mayer's Hematoxylin-Eosin. After imaging, the invasion depth of all invaded cells (area) in each microscopic field was determined by measuring the distance of the cell invasion front from the top cell layer on each disc using the Image J (Fiji) v1.46o (National Institute of Health, USA). Uterine leiomyoma tissues were obtained from routine surgeries of otherwise healthy donors after informed consent. The study was reviewed by the Regional Ethics Committee of the Northern Ostrobothnia Hospital District (license number 2/2017).

\section{Soft agar colony formation assay}

Black wall CellCarrier-96 Ultra Microplates (PerkinElemer, Inc, Waltham, Ma, US) was used in the soft agar colony formation assay. Pre-warmed $25 \mu \mathrm{l}$ of $2 \times$ Dulbecco's modified Eagle's medium (D-MEM; containing 20\% FBS, $200 \mathrm{U} / \mathrm{ml}$ penicillin, $200 \mu \mathrm{g} / \mathrm{ml}$ streptomycin, and $25 \mu \mathrm{l}$ of melted $1 \%$ Ultra Pure ${ }^{\mathrm{TM}}$ agarose (Thermo fisher scientific, CA, USA) solutions were mixed and transferred into each well and put at $4{ }^{\circ} \mathrm{C}$ for $30 \mathrm{~min}$ to allow the agar layer to solidify. Trypsinized cells $\left(2.5 \times 10^{3}\right.$ cells $)$ were then suspended in $25 \mu \mathrm{l}$ of D-MEM/10\% FBS and mixed with $25 \mu \mathrm{l}$ of $2 \times \mathrm{D}-\mathrm{MEM}$ containing $20 \%$ FBS and $25 \mu 1$ of $0.7 \%$ agar before adding the suspension on top of the solidified agar bed and cooling at $4{ }^{\circ} \mathrm{C}$ for $15 \mathrm{~min}$. After adding $50 \mu \mathrm{l}$ of $1 \times$ DMEM per well, the plates were incubated for 30 days at $37^{\circ} \mathrm{C}$ and $5 \% \mathrm{CO}_{2}$. The medium supplemented (or not) with $100 \mathrm{ng} / \mathrm{ml}$ doxycycline was changed every 2-3 days. Thirty days post-seeding, cells were fixed with $2 \%$ PFA at RT for $30 \mathrm{~min}$ and stained with the Hoechst 33,342 dye $(1 \mu \mathrm{g} / \mathrm{ml})$ at $37{ }^{\circ} \mathrm{C}$ and $5 \% \mathrm{CO}_{2}$ before imaging with the Operetta ${ }^{\mathrm{TM}}$ high content imaging system (PerkinElmer Inc.). Forty fields were acquired from each well using appropriate filter sets, and a $20 \times$ objective. Images were analyzed using the Harmony software with 
selected scripts to allow segmentation to cell colonies. Segmentation criteria included colony size ( $>3$ cells/colony), circularity, and fluorescence intensity of nuclei.

\section{Statistical analyses}

Statistical analysis was performed using either Excel or GraphPad Prism Software (GraphPad Software Inc., La Jolla, CA, USA). Unless stated otherwise, the comparison of medians $( \pm$ SD) between two groups was done by two-tailed Student's $t$ test, whereas multiple groups were compared by one-way ANOVA. All error bars represent standard deviation (SD) and the $p$ values $<0.05$ were considered statistically significant.

Supplementary Information The online version contains supplementary material available at https://doi.org/10.1007/s00018-021-03890-y.

Acknowledgements The authors wish to thank Dr. Antti Hassinen for his help in setting up the protocols for Operetta High Content Imaging System. Dr. Tomasz Wenta is acknowledged for help in making the cytoplasmic pHluorin construct. We also thank Maija-Leena Lehtonen and Tanja Kuusisto for expert technical assistance, M.Sc. Teemu Viinikangas for setting up the Genepix 4200AL laser scanner protocols. We acknowledge the University of Oulu Graduate School, the Finnish National Agency for Education (CIMO), the Thelma Mäkikyrö Foundation, and the Academy of Finland for funding.

Author contributions EK and AR performed the experiments, MR and TS provided help in myoma invasion assays. AT and MM provided the human colorectal tissue specimens with low-grade histology.

Funding Open access funding provided by University of Oulu including Oulu University Hospital.

Data availability The datasets generated during and/or analysed during the current study are available from the corresponding author (elham. khosrowabadi@oulu.fi) on reasonable request.

\section{Declarations}

Conflict of interest The authors declare no competing interests regarding this manuscript.

Ethics approval/consent to participate All uterine leiomyoma tissues were obtained from routine surgeries of otherwise healthy donors after their informed consent. The study protocol was reviewed and approved by the Regional Ethics Committee of the Northern Ostrobothnia Hospital District (license number 2/2017). All colorectal cancer and control tissue specimens were collected from the resection specimens from patients who had given their informed consent, according to the study protocol approved by Regional Ethics Committee of the Northern Ostrobothnia Hospital District (license numbers 42/2005, 122/2009, 99/2020).

Open Access This article is licensed under a Creative Commons Attribution 4.0 International License, which permits use, sharing, adaptation, distribution and reproduction in any medium or format, as long as you give appropriate credit to the original author(s) and the source, provide a link to the Creative Commons licence, and indicate if changes were made. The images or other third party material in this article are included in the article's Creative Commons licence, unless indicated otherwise in a credit line to the material. If material is not included in the article's Creative Commons licence and your intended use is not permitted by statutory regulation or exceeds the permitted use, you will need to obtain permission directly from the copyright holder. To view a copy of this licence, visit http://creativecommons.org/licenses/by/4.0/.

\section{References}

1. Hanahan D, Weinberg RA (2011) Hallmarks of cancer: the next generation. Cell 144:646-674

2. Webb BA, Chimenti M, Jacobson MP, Barber DL (2011) Dysregulated $\mathrm{pH}$ : a perfect storm for cancer progression. Nat Rev Cancer 11:671-677

3. Boedtkjer E, Pedersen SF (2020) The acidic tumour microenvironment as a driver of cancer. Annu Rev Physiol 82:103-126. https://doi.org/10.1146/annurev-physiol-021119-034627

4. Vajaria BN, Patel PS (2017) Glycosylation: a hallmark of cancer? Glycoconj J 34:147-156

5. Varki A, Kannagi R, Toole B, Stanley P (2017) Glycosylation changes in Cancer. In: Varki A et al (eds) Essentials of glycobiology, 3rd edn. Cold Spring Harbor Laboratory Press, New York, pp 597-609

6. Varki A, Gagneux P (2017) Biological functions of glycans. In: Varki A et al (eds) Essentials of glycobiology, 3rd edn. Cold Spring Harbor Laboratory Press, New York, pp 77-88

7. Tian E, Ten Hagen KG (2009) Recent insights into the biological roles of mucin-type O-glycosylation. Glycoconj $\mathrm{J}$ 26:325-334

8. Hakomori S (2001) Tumour-associated carbohydrate antigens defining tumour malignancy: basis for development of anti-cancer vaccines. Adv Exp Med Biol 491:369-402

9. van Kooyk Y, Rabinovich GA (2008) Protein-glycan interactions in the control of innate and adaptive immune responses. Nat Immunol 9:593-601

10. Oliveira-Ferrer L, Legler K, Milde-Langosch K (2017) Role of protein glycosylation in cancer metastasis. Semin Cancer Biol 44:141-152

11. Ma M, Fu Y, Zhou X, Guan F, Wang Y, Li X (2019) Functional roles of fucosylated and O-glycosylated cadherins during carcinogenesis and metastasis. Cell Signal 63:109365

12. Bhatia R, Gautam SK, Cannon A, Thompson C, Hall BR, Aithal A, Banerjee K, Jain M, Solheim JC, Kumar S, Batra SK (2019) Cancer-associated mucins: role in immune modulation and metastasis. Cancer Metastasis Rev 38:223-236

13. Kellokumpu S (2019) Golgi pH, ion and redox homeostasis: how much do they really matter? Front Cell Dev Biol 7:93

14. Khosrowabadi E, Kellokumpu S (2020) Golgi pH and ion homeostasis in health and disease. Rev Physiol Biochem Pharmacol. https://doi.org/10.1007/112_2020_49 (PMID: 32870398)

15. Rivinoja A, Hassinen A, Kokkonen N, Kauppila A, Kellokumpu S (2009) Elevated Golgi pH impairs terminal N-glycosylation by inducing mislocalization of Golgi glycosyltransferases. J Cell Physiol 220:144-154

16. Kokkonen N, Khosrowabadi E, Hassinen A, Harrus D, Glumoff T, Kietzmann T, Kellokumpu S (2019) Abnormal Golgi pH homeostasis in cancer cells impairs apical targeting of carcinoembryonic antigen by inhibiting its glycosyl-phosphatidylinositol 
anchor-mediated association with lipid rafts. Antioxid Redox Signal 30:5-21

17. Kellokumpu S, Sormunen R, Kellokumpu I (2002) Abnormal glycosylation and altered Golgi structure in colorectal cancer: dependence on intra-Golgi pH. FEBS Lett 516:217-224

18. Rivinoja A, Kokkonen N, Kellokumpu I, Kellokumpu S (2006) Elevated Golgi $\mathrm{pH}$ in breast and colorectal cancer cells correlates with the expression of oncofetal carbohydrate T-antigen. J Cell Physiol 208:167-174

19. Demaurex N (2002) pH Homeostasis of cellular organelles. News Physiol Sci 17:1-5

20. Paroutis P, Touret N, Grinstein S (2004) The $\mathrm{pH}$ of the secretory pathway: measurement, determinants, and regulation. Physiology (Bethesda) 19:207-215

21. Maeda Y, Ide T, Koike M, Uchiyama Y, Kinoshita T (2008) GPHR is a novel anion channel critical for acidification and functions of the golgi apparatus. Nat Cell Biol 10:1135-1145

22. Nordeen MH, Jones SM, Howell KE, Caldwell JH (2000) GOLAC: an endogenous anion channel of the golgi complex. Biophys J 78:2918-2928. https://doi.org/10.1016/S00063495(00)76832-9

23. Wu MM, Grabe M, Adams S, Tsien RY, Moore HP, Machen TE (2001) Mechanisms of $\mathrm{pH}$ regulation in the regulated secretory pathway. J Biol Chem 276:33027-33035

24. Schapiro FB, Grinstein S (2000) Determinants of the $\mathrm{pH}$ of the golgi complex. J Biol Chem 275:21025-21032

25. Nakamura N, Tanaka S, Teko Y, Mitsui K, Kanazawa H (2005) Four $\mathrm{Na}+\mathrm{H}+$ exchanger isoforms are distributed to golgi and post-golgi compartments and are involved in organelle $\mathrm{pH}$ regulation*. J Biol Chem 280:1561-1572

26. Milosavljevic N, Monet M, Léna I, Brau F, Lacas-Gervais S, Feliciangeli S, Counillon L, Poët M (2014) The intracellular $\mathrm{Na}+\mathrm{H}+$ exchanger NHE7 effects a Na+-coupled, but not $\mathrm{K}+-$ coupled proton-loading mechanism in endocytosis. Cell Rep 7:689-696

27. Galenkamp KMO, Sosicka P, Jung M, Recouvreux MV, Zhang Y, Moldenhauer MR, Brandi G, Freeze HH, Commisso C (2020) Golgi acidification by NHE7 regulates cytosolic $\mathrm{pH}$ homeostasis in pancreatic cancer cells. Cancer Discov 10:822. https://doi.org/ 10.1158/2159-8290.CD-19-1007

28. Holappa K, Suokas M, Soininen P, Kellokumpu S (2001) Identification of the full-length AE2 (AE2a) isoform as the Golgiassociated anion exchanger in fibroblasts. J Histochem Cytochem 49:259-269. https://doi.org/10.1177/002215540104900213

29. Romero MF, Fulton CM, Boron WF (2004) The SLC4 family of HCO3 - transporters. Pflugers Arch 447:495-509

30. Alper SL (2006) Molecular physiology of SLC4 anion exchangers. Exp Physiol 91:153-161

31. Gawenis LR, Ledoussal C, Judd LM, Prasad V, Alper SL, Stuart-Tilley A, Woo AL, Grisham C, Sanford LP, Doetschman T, Miller ML, Shull GE (2004) Mice with a targeted disruption of the $\mathrm{AE} 2 \mathrm{Cl}-/ \mathrm{HCO} 3-$ exchanger are achlorhydric*. J Biol Chem 279:30531-30539

32. Sterling D, Reithmeier RA, Casey JR (2001) A transport metabolon. Functional interaction of carbonic anhydrase II and chloride/ bicarbonate exchangers. J Biol Chem 276:47886-47894

33. McMurtrie HL, Cleary HJ, Alvarez BV, Loiselle FB, Sterling D, Morgan PE, Johnson DE, Casey JR (2004) The bicarbonate transport metabolon. J Enzyme Inhib Med Chem 19:231-236

34. Scozzafava A, Supuran CT (2002) Carbonic anhydrase activators: high-affinity isozymes I, II, and IV activators, incorporating a beta-alanyl-histidine scaffold. J Med Chem 45:284-291

35. Boron WF (2010) Evaluating the role of carbonic anhydrases in the transport of HCO3-related species. Biochim Biophys Acta 1804(2):410-421. https://doi.org/10.1016/j.bbapap.2009.10.021
36. Holappa K, Kellokumpu S (2003) Targeting of the AE2 anion exchanger to the Golgi apparatus is cell type-dependent and correlates with the expression of Ank195, a Golgi membrane skeletal protein. FEBS Lett 546:257-264

37. Beck KA, Nelson WJ (1998) A spectrin membrane skeleton of the Golgi complex. Biochim Biophys Acta Mol Cell Res 1404:153-160

38. Miesenböck G, De Angelis DA, Rothman JE (1998) Visualizing secretion and synaptic transmission with $\mathrm{pH}$-sensitive green fluorescent proteins. Nature 394:192-195

39. Bhakdi S, Weller U, Walev I, Martin E, Jonas D, Palmer M (1993) A guide to the use of pore-forming toxins for controlled permeabilization of cell membranes. Med Microbiol Immunol 182:167-175

40. Verma RK, Gupta AB, Sankararamakrishnan R (2015) Major intrinsic protein superfamily: channels with unique structural features and diverse selectivity filters. Methods Enzymol 557:485-520

41. Laloux T, Junqueira B, Maistriaux LC, Ahmed J, Jurkiewicz A, Chaumont F (2018) Plant and mammal aquaporins: same but different. Int J Mol Sci 19:521

42. Occhipinti R, Boron WF (2015) Mathematical modeling of acidbase physiology. Prog Biophys Mol Biol 117:43-58

43. Lodish H, Berk A, Zipursky SL, et al (2000) Molecular cell biology. In: Freeman WH, Intracellular ion environment and membrane electric potential, 4th edn, New York. https://www.ncbi.nlm. nih.gov/books/NBK21627

44. Åström P, Heljasvaara R, Nyberg P, Al-Samadi A, Salo T (2018) Human tumour tissue-based $3 \mathrm{D}$ in vitro invasion assays. In: Methods in molecular biology, vol 1731. United States Publisher, Clifton, New Jersey, pp 213-221

45. Dennis JW (1991) N-linked oligosaccharide processing and tumour cell biology. Semin Cancer Biol 2:411-420

46. Hakomori S (2002) Glycosylation defining cancer malignancy: new wine in an old bottle. Proc Natl Acad Sci USA 99:10231-10233

47. Lau KS, Dennis JW (2008) N-glycans in cancer progression. Glycobiology 18:750-760

48. Dell A, Galadari A, Sastre F, Hitchen P (2010) Similarities and differences in the glycosylation mechanisms in prokaryotes and eukaryotes. Int J Microbiol 2010:148178-148192. https://doi.org/ 10.1155/2010/148178

49. Gagneux P, Aebi M, Varki A (2017) Evolution of glycan diversity. In: Varki A, Cummings RD, Esko JD, et al (eds) Essentials of Glycobiology [Internet], 3rd edn, chap 20. Cold Spring Harbor Laboratory Press, Cold Spring Harbor, pp 2015-2017. https://doi. org/10.1101/glycobiology.3e.020

50. Stewart AK, Kurschat CE, Vaughan-Jones RD, Alper SL (2009) Putative re-entrant Loop 1 of AE2 transmembrane domain has a major role in acute regulation of anion exchange by $\mathrm{pH}^{*}$. J Biol Chem 284:6126-6139

51. Ruetz S, Lindsey AE, Ward CL, Kopito RR (1993) Functional activation of plasma membrane anion exchangers occurs in a preGolgi compartment. J Cell Biol 121:37-48

52. Malkhosyan S, Yasuda J, Soto JL, Sekiya T, Yokota J, Perucho M (1998) Molecular karyotype (amplotype) of metastatic colorectal cancer by unbiased arbitrarily primed PCR DNA fingerprinting. Proc Natl Acad Sci USA 95:10170

53. Karumanchi SA, Jiang L, Knebelmann B, Stuart-Tilley AK, Alper SL, Sukhatme VP (2001) VHL tumour suppressor regulates Cl-/ $\mathrm{HCO} 3$-exchange and $\mathrm{Na}+\mathrm{H}+$ exchange activities in renal carcinoma cells. Physiol Genomics 5:119-128

54. Jiang Y, Wen T, Yan R, Kim SR, Stowell SR, Wang W, Wang Y, An G, Cummings RD, Ju T (2020) O-glycans on death receptors in cells modulate their sensitivity to TRAIL-induced apoptosis through affecting on their stability and oligomerization. FASEB J 34:11786-11801 
55. Nguyen AT, Chia J, Ros M, Hui KM, Saltel F, Bard F (2017) Organelle specific O-glycosylation drives MMP14 activation, tumour growth, and metastasis. Cancer Cell 32:639-653.e6

56. Marsico G, Russo L, Quondamatteo F, Pandit A (2018) Glycosylation and integrin regulation in cancer. Trends Cancer 4:537-552

57. Cai X, Thinn AMM, Wang Z, Shan H, Zhu J (2017) The importance of N-glycosylation on $\beta 3$ integrin ligand binding and conformational regulation. Sci Rep 7:4656

58. Kuo T, Wu M, Yang S, Chen S, Hsu T, Jhuang J, Liao Y, Tien Y, Huang M (2021) C1GALT1 high expression is associated with poor survival of patients with pancreatic ductal adenocarcinoma and promotes cell invasiveness through integrin $\alpha v$. Oncogene 40:1242-1254. https://doi.org/10.1038/s41388-020-01594-4

59. Morava É, Guillard M, Lefeber D, Wevers RA (2019) Autosomal recessive cutis laxa syndrome revisited. Eur J Hum Genet 17:1099-1110. https://doi.org/10.1038/ejhg.2009.22

60. Kornak U, Reynders E, Dimopoulou A, van Reeuwijk J, Fischer B, Rajab A, Budde B, Nürnberg P, Foulquier F, Dobyns WB,
Quelhas D, Vilarinho L, Leao-Teles E, Greally M, Seemanova E, Simandlova M, Salih M, Nanda A, Basel-Vanagaite L, Kayserili H, Yuksel-Apak M, Larregue M, Vigneron J, Giurgea S, Kornak U, Mundlos S, Lefeber D, Urban Z, Gruenewald S, Annaert W, Brunner HG, van Bokhoven H, Wevers R, Morava E, Matthijs G, Van Maldergem L, Mundlos S and the ARCL Debré-type, Study Group (2008) Impaired glycosylation and cutis laxa caused by mutations in the vesicular H+-ATPase subunit ATP6V0A2. Nat Genet 40:32-34. https://doi.org/10.1038/ng.2007.45

61. Parkkila S, Rajaniemi H, Kellokumpu S (1993) Polarized expression of a band 3-related protein in mammalian sperm cells. Biol Reprod 49:326-331

Publisher's Note Springer Nature remains neutral with regard to jurisdictional claims in published maps and institutional affiliations. 